Yücel Çetin, D. ve Mangır, M. (2021). Çocuk kitaplarında cinsiyet algısının dile yansıması. Ana Dili Eğitimi Dergisi, 9(1), 166-187.

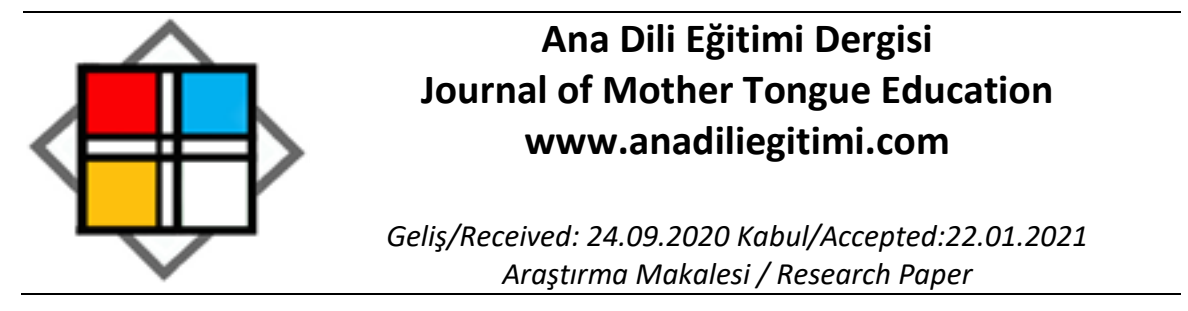

\title{
Toplumsal Cinsiyet Rollerinin Çocuk Kitaplarına Yansıması*
}

\author{
Derya YÜCEL ÇETIN** \\ Mediha MANGIR***
}

Öz

Bu araştırmada, Milî̃ Eğitim Bakanlığı tarafından 2005 yılında yayımlanan ve 2018 yılında yürürlükten kaldırılan ortaokul öğrencilerine yönelik hazırlanmış 100 Temel Eser'in söz konusu eğitim-öğretim kademesinde yakın zamana kadar en çok tercih edilen kitap listesi olduğu varsayımından hareketle bu kitaplara toplumsal cinsiyet rollerinin ne şekilde yansıdığının tespiti amaçlanmıştır. Bu amaç doğrultusunda 100 Temel Eser metinleri içerisindeki toplumsal cinsiyeti yansıtan ifadeler tespit edilmiştir. Araştırmanın verileri, 100 Temel Eser içerisinde yer alan Türk edebiyatına ait olaya dayalı metinlerden tarama modeli ile elde edilmiştir. Araştırmanın amacına yönelik olarak veriler belirlenen kategoriler çerçevesinde değerlendirilmiş, kategori türlerinden ise 'kişilere ve aktörlere göre kategoriler' seçilmiştir. Araştırmanın ana izleği çocuk kitaplarında eril ve dişil cinsiyetin ne şekilde yansıtıldığıdır. Ana izleğe bağlı olarak alt kategoriler; "dişil cinsiyeti aşağılayıcı söylemler, eril cinsiyeti yüceltici söylemler, dişil ve eril cinsiyetin günlük yaşamdaki rolleri" olarak belirlenmiştir. Belirlenen kategorilere ait tüm veriler araştırmaya dâhil edilmiş ve içerik analizi türlerinden frekans analizi ile verilerin sıklık ve yüzdeleri hesaplanmıştır. Hesaplanan sıklık ve yüzdeler tablolarda gösterilmiş ve yorumlanmıştır. ilggili kategorilere ait verilerin tamamına, çalışmanın hacmini artırmaması sebebiyle yer verilmemiş̧ir. Araştırmadan elde edilen bulgulardan hareketle 100 Temel Eser'de toplumsal cinsiyet rollerinin adalet temelli bir anlayışla sunulmadığı, aksine eril cinsin pek çok konuda dişil cinsten üstün görüldüğü sonucuna ulaşılmıştır.

Anahtar Kelimeler: Türkçe Eğitimi, Çocuk Edebiyatı, Toplumsal Cinsiyet, 100 Temel Eser

\begin{abstract}
Based on the assumption that the 100 Basic Works List, published by the Ministry of National Education in 2005 and annulled in 2018, was the most preferred book list until recently for the secondary school students, this study aims to determine whether gender perception in these books has been presented in a justice-based understanding or not. In line with this objective, expressions which reflects gender in 100 Basic Works texts were detected. The data of the research were obtained from the narration-based texts of Turkish literature included in 100 Basic Works by scanning model. In parallel with the purpose of the research, the data have been evaluated within the scope of specified categories, and among the category types, "categories for people and actors" have been selected. The main theme of the research is how different the female and male sex are perceived in the context of gender. Subcategories depending on the main theme have been specified as "discourses degrading the feminine sex, expressions glorifying the masculine gender, the roles of the female and masculine in daily life". All data about the specified categories have
\end{abstract}

Reflection of Gender Perception on Language in Children's Books

\footnotetext{
* Bu makale, birinci yazarın ikinci yazar danışmanlığında hazırladığı “100 Temel Eser'de Cinsiyet Rollerinin Dile Yansıması" adlı yüksek lisans tezinden üretilmiştir.

** Araştırma Görevlisi, Atatürk Üniversitesi, Eğitim Bilimleri Enstitüsü, Türkçe ve Sosyal Bilimler Eğitimi Ana Bilim Dalı, deryayucelcetin@outlook.com, ORCID: orcid.org/ 0000-0001-7608-5926

*** Dr. Öğretim Üyesi, Ondokuz Mayıs Üniversitesi, Eğitim Fakültesi, Türkçe ve Sosyal Bilimler Eğitimi Bölümü, mediha.mangir@omu.edu.tr, ORCID: orcid.org/ 0000-0001-9455-7042
} 
been included in the study and the frequency and percentages of the data were calculated with frequency analysis, which is one of the content analysis types. Calculated frequencies and percentages have been shown in tables and interpreted. All of the data about the related categories have not been presented as evidence so as not to enlarge the scope of the study. Based on the findings obtained from the research, it has been concluded that the perception of gender is not presented with a justice-based approach in 100 Basic Works, on the contrary, the masculine gender is seen as superior to the feminine gender in many issues.

Keywords: Turkish Education, Children's Literature, Gender, 100 Essential Works

\section{Giriş}

Dünya üzerindeki tüm kültürlerde insan, biyolojik nedenlere bağlı olarak genellikle kadın ve erkek olarak iki ayrı terimle karşılanır. Bu iki cins, doğuştan getirdiği hormonal, fiziksel ve bilişsel farklııklar sebebiyle birbirlerinden ayrıır. Bunun dışında kadın ve erkeğin içinde yaşadığı çevrenin sahip olduğu kültürel anlayış, somut ve nesnel olmayan bazı özellikleri bu iki cinse yüklemeye çalışır. Bu farklar biyolojik farklar gibi her insan için genellenemez. Toplumdan topluma değişebileceği gibi aynı toplumda farklı zamanlarda yaşamış kişiler için de değişiklik gösterebilir. Türkçede biyolojik farklar 'cinsiyet' ile, içinde yaşanılan kültürün etkisiyle sonradan edinilmiş farklar ise 'toplumsal cinsiyet' kavramıyla karşılanır (Vatandaş, 2001: 31). Yeşil (2014: 12)'e göre farklı yaşantıların, farklı kültürlerin ve inançların, farklı zaman dilimlerinin etkisi toplumsal cinsiyete dinamik bir nitelik kazandırır.

Cinsiyeti doğa belirlerken, toplumsal cinsiyeti içinde yaşanılan kültür belirler. Toplumsal cinsiyet kimliği hakkındaki kabuller, bunlarla bağlantılı olan cinsel tutum ve eğilimlerin de etkisiyle çok erken yaşlarda belirlenir (Uluocak ve Aslan, 2011: 26).

Her kültür, kendi inançları ve yaşam tarzı göz önünde bulundurulduğunda pek çok açıdan birbirinden farklı özellikler taşır. Toplumdan topluma 'Kadın ve erkeğin günlük yaşamdaki rolü nedir? Kadın ve erkeğin uğraş alanları nelerdir? Kadın ve erkek nasıl giyinir?' gibi soruların yanıtları değişebilir. Kadın ve erkek için oluşturulmuş kalıp yargılar, cinsiyetlerin günlük yaşam içindeki konumlanışı ve yaşayışını doğrudan etkiler.

Toplumsal cinsiyet bağlamındaki farkların sosyo-ekonomik çevrenin etkisiyle mi yoksa biyolojik olarak farklı yaradılış özelliklerinin tesiriyle mi oluştuğu sorusu bilim insanlarını ikiye bölmüştür (Uluocak ve Aslan, 2011: 25). Özellikle beyin araştırmalarının hız kazandığı son yüzyılda cinslerin farklı beyin yapılarına sahip olduğu düşüncesi hâkim olmaya başlamıştır. Beyin yapılarındaki farklılığın daha ceninin anne karnındaki ilk oluşum haftalarında hormonların etkisiyle şekillendiği savunulmuştur (Moir ve Jessel, 2002; Fine, 2017).

Moir ve Jessel (2002: 31) yaptıkları araştırmalar neticesinde, karşı cinslere ait olarak gelişen stereotiplerin ve bu cinslere ait toplumsal değerlerin bilimsel olarak da kanıtlanabilen temelleri olduğu sonucuna varmışlardır. Araştırmacılar, toplumsal cinsiyet farklılıkları olarak ifade edilen durumların aslında iki cinsin beyin yapısı ve hormonlarının farklı olmasından kaynaklandığını savunur.

Bu görüşün aksini savunan araştırmacıların sayısı da yadsınamayacak kadar çoktur (Giddens, 2012; Akbalık, 2014; Powell ve Greenhaus, 2010). Çubukçu ve Sivaslıgil (2007: 8)'e göre toplumsal cinsiyet, doğuştan kazanılan biyolojik cinsiyetten farklı olarak, toplumsal ve kültürel olarak her iki cinse yüklenen rollerin toplamıdır. Birey bu rolleri doğumundan itibaren ailesi ve daha geniş toplumsal çevresindeki deneyimleri aracılığıyla öğrenir. Bu farklılıkların kaynağı, bireyin fizyolojik özellikleri değil, toplumun dayattı̆̆ı sonradan öğrenilen kalıplardır.

Toplumsal cinsiyet farkları doğuştan getirilen fizyolojik özelliklerden de oluşsa sonradan da öğrenilse netice itibarıyla iki cins arasında meslek seçiminden olaylara bakış açısına, çocukluk dönemi oyunlarından çocuk yetiştirme konusuna, aile içindeki rollerden cinsler için kullanılan niteleyicilere kadar pek çok açıdan ayrım olduğu hemen hemen herkes tarafından kabul gören bir gerçektir.

Toplumsal cinsiyet rolleri söz konusu olduğunda erilin dişile göre daha avantajlı olduğu söylenebilir. Roller genellikle erkeğin lehine olacak şekilde düzenlenmiş, erkeğin mala ve güce sahip cins olma özelliği yüzyıllardır süregelmiştir (Adler, 1999: 12). Bu genel kanının oluşmasının temelinde ilk insanların savaşarak kendi bölgelerini koruma isteği yatar. Erkeğin fiziksel olarak daha güçlü oluşu savaşlarda ön plana çıkmasına vesile olmuş, bunun neticesinde de erkeğe toplumda görece daha 
önemli cinsiyet olma özelliği kazandırmıştır. Erkek, toplum içindeki konumunu belirlerken bu özelliğinin artısıyla, kadına kendi çıkarlarına ters düşmeyecek roller çizmiştir. Kadın, aile ve toplum içindeki yaşantısında erkeğe göre geri planda kalmış, emek gerektiren işlerde başrolü oynamıştır. Ecevit (2012:20)'e göre kadın ve erkeğin rollerinin analizinde, erkek aile içinde olduğu kadar dış dünya ile ilişkileri açısından da incelenirken kadın sadece aile içinde oynadığı roller bağlamında bu analizin içine girmiştir.

iki cins arasındaki toplumsal cinsiyet kalıp yargıları çocukluk döneminde başlar ve çocuk büyürken onunla büyür. Daha küçücük bir bebekken 'nazlı kızım', 'aslan oğlum' sözleriyle duygulara ve düşüncelere yerleşir (Gümüşoğlu, 2016: 60). Erkek ve kız çocuk için seçilen kıyafet ve eşyaların renkleri de cinsiyete göre belirlenir ve iki ayrı kategoride üretilir. Kız çocukları için üretilen oyuncaklara bakıldığında bebek, yemek pişirme araçları, beşik, temizlik malzemeleri gibi daha çok gelecek yaşantısında kullanması beklenen araçlar olduğu görülürken; erkek oyuncakları için üretilen oyuncaklarda ise savaşçı karakterler, arabalar, iş makineleri, silahlar gibi oyuncaklar görülmektedir (Göktaş, 2020: 33). İstisnalar olsa da bebekliğinden beri arabayla oynayan bir cinsin şoförlüğe daha yatkın olması beklenen bir sonuçtur. Aynı şekilde tüm çocukluğunda oyuncak mutfak malzemeleri ile oynayan bir kız çocuğunun büyüdüğünde mutfak işlerinde başarılı olması oldukça doğaldır. Burada kastedilen aş̧̧ılık mesleğinde hangi cinsin daha başarılı olduğu değil günlük yaşamda aile içi mutfak işlerinde hangi cinsin daha aktif olduğudur.

Çocuk okul çağına geldiğinde sosyal çevrenin daha fazla etkisinde kalır. Okul öncesi dönemde çocukların karakter ve düşünce yapısı aileye, çevreye ve günümüzde çok etkili olan kitle iletişim araçlarının ilettiği mesajlara göre şekillenir (Güder, Ay, Saray ve Kılıç, 2017). Okul çağında ise çocuk, arkadaşlarından ve öğretmenlerinden etkilenerek toplumun kültürel kimliğine bürünür. Hatta bu dönem çocukları okumayı öğrendikleri andan itibaren karşılaştıkları tüm yazılı materyallerden kendilerine olumlu veya olumsuz düşünceler katar. Çocuk, yaşadıkları ve okuduklarından edindiği tecrübe ile kendine bir dünya görüşü oluşturur. Bu görüş olumsuz anlamda şekillenmeden önce, çocuğu adalet temelli cinsiyet algısı oluşturacak eserler ile buluşturmak gerekir. Elbette bir sanat eserinin eğitsel bir kaygıyla ya da doğru model sunma-yanlış model sunma ikilemiyle oluşturulması beklenmez (Dökmen, 2017: 143). Bu nedenle aile ve öğretmenlere çocuğun seviyesine uygun eser seçimi konusunda büyük görev düşer.

Ana malzemesi dil olan ve metinler vasıtasıyla işlenen Türkçe dersi, öğrenciyi doğru eserlerle buluşturmada en büyük paya sahiptir. Gündüz ve Şimşek (2011: 61)'e göre ders kitaplarındaki metinleri okutmak okuma zevki ve alışkanlığı kazandırmada yeterli değildir. Öğretmen, ders kitabı dışında da Türkçenin güzel kullanıldığı metinleri bulup sınıfa getirmeyi ve öğrencilere okutmayı ilke edinmiş olmalıdır. Çünkü çocuklar bu ürünleri okuyarak kendi beğenilerini geliştirir ve okuma isteği duydukça da çocukların okuma alışkanlığını kazanması beklenir (Arı ve Okur, 2019: 309). Şirin (2007: 31)'e göre okuma becerisinin kazandırımasında en etkili yöntem, nitelikli çocuk edebiyatı örneklerinin çocuğa sunulmasıdır.

Dil, toplumun hayat felsefesinden, değerlerinden, kadına ve erkeğe bakış açısından bağımsız olmadığı için (Çolak, 2019: 109) seçilen eserlerin dili öğrencilerin seviyesine uygunluğu esas alınarak incelenmelidir. Ortaokul öğrencilerinin alıcı söz varlığına kazandırılması beklenen sözcükler ve sözcük gruplarının bilişsel ve zihinsel gelişimlerine uygun olup olmadığı ancak bu sayede tespit edilebilir.

Millî Eğitim Bakanlığı 2018'de yayımladığı genelge ile 2005 yılından beri yürürlükte olan 100 Temel Eser uygulamasına son vermiştir. Bu tarihe kadar 100 Temel Eser, Türkçe öğretmenleri tarafından öğrencilere önerilmesi beklenen kitap listesiydi. Bu uygulamanın yürürlükten kaldırılması ile her öğretmen kendi deneyimlerine dayanarak kitap önerisi listesi hazırlamaktadır.

100 Temel Eser uygulamasının 13 sene yürürlükte kalması ve yürürlükten kalkmasından bu yana geçen kısa süre, ortaokul öğrencileri tarafından okunan kitapların çoğunun bu listeden oluştuğunu düşündürmektedir.

Türkiye'de geçmişten günümüze en çok tartışılan konulardan biri kadın ve erkek rollerinin adaletsiz dağııımıdır. Günlük yaşamda kadının hep ikinci plana atılması, ev işlerinden sorumlu cins olarak kadının görülmesi, çalışma hayatı söz konusu olduğunda kadının statüsü düşük işlerde 
çalıştırılması ya da erkekle aynı işi yapsa dahi daha düşük ücret alması, fiziksel veya psikolojik şiddet söz konusu olduğunda akla hemen kadının gelmesi vb. bu adaletsizliğin akla gelen ilk göstergeleridir.

Kadın ve erkek arasındaki adaletsizliğe dayalı algının kırılması ancak eğitim ile mümkündür. İstendik yönde davranış değişikliği, çocuğun kendi yaşantıları yoluyla çevresinde olup bitenleri özümsemesiyle olabileceği gibi iyi bir öğretmen rehberliğinde seçtiği okuma kitaplarını içselleştirerek de gerçekleşebilir. Bu bağlamda Türkçe dersi ve öğretmenleri, diğer derslere oranla öğrencileri daha çok eserle buluşturması bakımından önemlidir. Türkçe Dersi Öğretim Programı (2019) özel amaçlarından biri "okuduğu, dinlediği/izlediğinden hareketle, söz varlığını zenginleştirerek dil zevki ve bilincine ulaşmalarının; duygu, düşünce ve hayal dünyalarını geliştirmelerinin sağlanması"dır. Öğrencilerin okuduklarından hareketle duygu, düşünce ve hayal dünyalarını zenginleştirmesi amaçlanıyorsa okuyacağı eserlerin seçimi konusunda oldukça hassas davranılmalıdır.

Araştırmada, toplumsal cinsiyet rollerinin çocuk kitaplarına ne şekilde yansıdığının tespiti amaçlanmaktadır. Bu amaç doğrultusunda araştırmada yanıtı aranan problem soruları şunlardır:

Toplumsal cinsiyet rolleri çocuk kitaplarına yansımış mıdır?

Çocuk kitaplarında toplumsal cinsiyeti hangi göstergeler karşılar?

100 Temel Eser'de yer alan çocuk kitapları, adalet temelli cinsiyet algısı oluşturmak için Türkçe dersi kapsamında öğrencilere güvenle önerilebilir mi?

\section{Araştırmanın Modeli}

\section{Yöntem}

$\mathrm{Bu}$ araştırmada, toplumsal cinsiyet rollerinin çocuk kitaplarına ne şekilde yansıdığı tespit edilmeye çalışılmıştır. Bu amaç doğrultusunda yapılan araştırma, tarama modeli niteliği taşımaktadır. "Tarama modelleri, geçmişte ya da halen varolan bir durumu varolduğu şekliyle betimlemeyi amaçlayan araştırma modelleridir. Araştırmaya konu olan olay, birey ya da nesne, kendi koşulları içinde ve olduğu gibi tanımlanmaya çalışılır" (Karasar, 2011: 77).

\section{Veri Kaynakları}

Millî Eğitim Bakanlığı (2005), Türkçe öğretmenlerine yol gösterici olması ve eğitimde birliği sağlamak amacıyla 100 Temel Eser adı altında bir kitap listesi belirlemiştir. Bu liste içerisinde; ortaokul düzeyine uygun olduğu düşünülen, Türk ve yabancı yazarlar tarafından kaleme alınan ve farklı edebî türlerden oluşan kitaplar yer alır. MEB'in bu uygulaması yaklaşık on üç yıl yürürlükte kalmış, 17.12.2018 tarihinde yayımlanan bir genelge ile 100 Temel Eser uygulamasına son verilmiştir. Araştırmada, 100 Temel Eser uygulamasının yakın zamanda son bulması hasebiyle ortaokul öğrencileri tarafından en çok okunan kitapların bu listedeki kitaplar olduğu varsayılmıştır.

Araştırmada incelenen dokümanlar, MEB (2005) tarafından ortaokul seviyesindeki öğrencilere önerilen 100 Temel Eser içinden seçilmiştir. 100 Temel Eser, Türk ve dünya edebiyatından seçilen eserlerden oluşur.

100 Temel Eser'de bulunan yabancı yazarların eserleri, Türk yaşayışını ve Türklerin cinsiyet algısını yansıtmayacağı düşüncesi ile araştırmaya dâhil edilmemiştir. 100 Temel Eser'de bulunan Türk edebiyatı seçkileri hikâye, roman, şiir, masal, deneme, anı gibi türlerin yanı sıra; atasözü, deyim, özlü sözler, tekerleme, mâni ve ninnilerin derlendiği eserlerden oluşmaktadır.

$\mathrm{Bu}$ araştırmada, 100 Temel Eser'de geçen toplumsal cinsiyet rolleri metin içi bağlamdan hareketle cümle düzeyinde incelenmiştir. Şiir, deneme, atasözü, deyim, özlü sözler, tekerleme, mâni, ninni gibi edebî türlerdeki eserlerin derleme niteliğinde olması ve bu metinlerde anlatısal bağlamın bulunmaması nedeniyle araştırmaya dâhil edilmemiştir.

Aktaş (2009)'a göre edebî metin; düşünülen, tasarlanan gerçekliği eserin ortaya konulduğu dönemin düşünüş şekli, zevki ve anlayışından hareketle yorumlayıp dönüştürerek insana ait bir özelliği somutlaştırarak dile getirir. Yani edebî metin, gerçeklikten hareketle daha kapsayıcı ve kuşatıcı bir gerçeklik sunar. Bu düşünceden hareketle araştırmada Türk yaşayışını ve Türklerin cinsiyetlere yüklediği rollerin gerçekçi bir şekilde yansıtıldığı düşünülen edebî eserler incelenmiştir. 
Incelenecek eserde anlatısal bağlamın olması ve metin kahramanlarını ayrıntılı tanıma imkânı; yazarın eserde yansıttığı toplumsal cinsiyet rolünü belirleme noktasında önemlidir. Bu nedenle roman, hikâye, masal ve anılardan oluşan otuz üç eser araştırmanın veri kaynaklarını oluşturmuştur.

\section{Verilerin Toplanması}

Nitel araştırmalarda içerik analizi yönteminde en sık kullanılan analiz birimleri sözcük ve cümlelerdir. Araştırılan konu ile ilgili oluşturulmuş kategoriler doğrultusunda incelenen dokümanlarda geçen sözcük veya cümleler kaydedilir. Araştırmada incelenen eserler toplumsal cinsiyet rolleri bağlamında taranmış; elde edilen veriler anlam bütünlüğünü bozmaması için, özgün biçimiyle, bir veya birkaç cümle şeklinde kaydedilmiştir. Önceden belirlenen kategorilere uygun verilere özellikle dikkat edilmiş, veriler eril veya dişil cinse gönderim yapmasına göre ayrıca tasnif edilmiştir.

Verileri kaydederken araştırmaya dâhil edilen cümle veya cümlelerin sonuna parantez içinde 'eser adı, sayfa numarası/satır numarası' bilgileri eklenmiş ve hangi cümlenin nereden alındığına dair bilgiye ulaşılması sağlanmıştır. Eğer kullanılacak cümle veya cümleler bir sayfanın sonu ile takip eden sayfanın başında yer alıyorsa, karışıklığa sebebiyet vermemek için, cümlenin başladığı sayfa esas alınmış ve kayıtta bir sonraki sayfanın numarası yazılmamıştır.

\section{Verilerin Analizi}

Çalışmada toplanan verilere içerik analizi uygulanmıştır. İçerik analizi yönteminde en önemli aşamalardan biri araştırmanın amacına uygun kategorilerin belirlenmesidir. Kategoriler sayesinde elde edilen veriler ham veri olmaktan çıkar ve sistemli verilere dönüşür (Tavşancıl \& Aslan, 2011: 72). Çalışmanın amacına uygun olarak kategori türlerinden kişilere ve aktörlere göre kategoriler seçilmiştir. Çalışmanın ana izleği çocuk kitaplarında eril ve dişil cinsiyetin ne şekilde yansıtıldığıdır. Ana izleğe bağlı olarak alt kategoriler; "dişil cinsiyeti aşağılayıcı söylemler, eril cinsiyeti yüceltici söylemler ve dişil ve eril cinsiyetin günlük yaşamdaki rolleri" olarak belirlenmiştir.

Toplumsal cinsiyet rollerinin çocuk kitaplarına yansımasını betimlemeye yönelik bu araştırmada, MEB (2005) tarafından önerilen 100 Temel Eser içinden seçilmiş anlatısal eserlerde, dişil ve eril cinsiyetin belirlenen kategoriler bağlamında elde edilen veriler içerik analizi türlerinden frekans analizi tekniği ile incelenmiştir. Illgili kategorilere ait veriler çalışmaya dâhil edilerek sıklıkları ve yüzdeleri hesaplanmıştır. Hesaplanan sıklıklar ve yüzdeler tablolarda gösterilmiş ve tablolardan hareketle betimlenmiştir. Tablolarda sıklık ve yüzde hesaplanırken ilgili kategorilere ait tüm veriler dâhil edilmiş fakat çalışmanın hacmini artırmaması amacıyla belli bir kısmı tanık olarak sunulmuştur.

\section{Bulgular}

Çalışmanın bu bölümünde içerik analizi ile elde edilen bulgular "dişil cinsiyeti aşağılayıcı söylemler, eril cinsiyeti yüceltici söylemler ve dişil ve eril cinsiyetin günlük yaşamdaki rolleri" başlıkları altında sunulmuştur.

\section{Dişil Cinsiyeti Aşağılayıcı Söylemler}

Tablo 1.

Dişil Cinsiyeti Aşağılayıcı Söylemlerin Sıklık ve Yüzdeleri

\begin{tabular}{lll} 
& $f$ & $\%$ \\
\hline Cinsel Obje Olarak Görülen & 7 & 9,09 \\
Fiziksel Olarak Öne Çıkan & 9 & 11,68 \\
Güçsüz ve Korunmaya Muhtaç & 4 & 5,19 \\
Küfür ve Argo Malzemesi & 24 & 31,16 \\
Zihinsel Olarak Geri & 9 & 11,68 \\
Eril Cinsiyete Muhtaç & 9 & 11,68 \\
Diğer & 15 & 19,48 \\
\hline Toplam & 77 & 100 \\
\hline
\end{tabular}


Bu bölümde, taranan eserler dişil cinsiyeti aşağılayıcı söylemler bağlamında incelenmiş ve 77 veriye ulaşılmıştır. Dişil cinsiyeti aşağılayıcı söylemler 7 alt başlık altında değerlendirilmiş ve Tablo $1^{\prime}$ de gösterilmiştir. Dişil cinsiyetin cinsel obje olarak görüldüğü $7(\% 9,09)$, fiziksel özellikleriyle ön plana çıktığı 9 (\%11,68), güçsüz ve korunmaya muhtaç olarak görüldüğü $4(\% 5,19)$, küfür ve argo ifadelere malzeme edildiği 24 (\%31,16), zihinsel olarak geri görüldüğü $9(\% 11,68)$, eril cinsiyete muhtaç görüldüğü $9(\% 11,68)$ ve bu kategorilere dâhil edilemeyen diğer $15(\% 19,48)$ veri saptanmıştır.

Taranan eserler dişil cinsiyeti aşağılayıcı söylemler bakımından incelendiğinde elde edilen veriler, yukarıdaki tabloda belirtilen alt başlıklar halinde gruplanarak aşağıda listelenmiştir:

\section{Dişil Cinsiyetin Cinsel Obje Olarak Görülmesi}

$\checkmark$ "Ya Pakize'yi yuvarlamaya azmetmiş bir çapkın..." (Tanrı Misafiri, 53/1-2)

$\checkmark \quad$ "Minimini bir Rum kızı... -Ayol, pek küçük! dedim. -Küçükse sen zihninde büyüt. ỉki kat hayal, bir hakikat yerini tutar." (Yalnız Efe, 150/1-4)

$\checkmark$ "Düşman, köyleri, kasabaları ateşe veriyor, erkekleri, çocukları öldürüyor, sığırları sürüp götürüyor, işe yarar ne varsa alıkoyuyor, genç kızları ve kadınları eğlence ediyormuş." (Yer Altında Bir Şehir, 39/27-30)

$\checkmark$ "Herifi azdır. Seni öpmeye kalkışsın." (Yalnız Efe, 29/25)

$\checkmark$ "Irza geçmiştim." (Seçme Hikâyeler, 104/29-30)

\section{Dişil Cinsiyetin Fiziksel Özellikleriyle Ön Plana Çıkması}

$\checkmark$ "Civarın en güzel kızlarını zorla nikahına alıyor, bir hafta sonra boşayıveriyordu." (Yalnız Efe, $117 / 12-13)$

$\checkmark$ "Etrafında birçok genç ilaheler çııılçıplak, -tıpkı meşhur Maison Americaine'deki kızlar gibibellerini çökertiyor ve memelerini dışarı çıkararak şuh ve nefis reveranslar yapıyorlardı." (Yalnız Efe, 90/11-14)

$\checkmark$ "Aman Ya Rabbi! Ya kalçaları." (Yalnız Efe, 43/16)

$\checkmark$ "Ama matmazel de ne piliç maşallah..." (Tanrı Misafiri, 71/12-13)

$\checkmark$ "işste kollarım, işte gerdanım, işte göğsüm karşınızda çırılçıplaktır, dedim. Siz de içinizi bana bu kadarcık açmak samimiyetini gösteriniz." (Hep O Şarkı, 95/9-11)

$\checkmark$ "Hayali sırtımda sıcak ürpermeler gezdiren iri, fırlak göğüslerini, dar cepkeni taşıracakmış gibi sıkıyor." (Yalnız Efe, 44/5-6)

\section{Dişil Cinsiyetin Güçsüz ve Korunmaya Muhtaç Görülmesi}

$\checkmark$ "Burada bu kadar kız var, kadın var. Onlar bizim namusumuzdur." (Yer Altında Bir Şehir, 65/24)

$\checkmark$ "Nazı bir erkek gibi silah kullanmasını biliyordu. Yine bir erkek kadar cesurdu." (Yer Altında Bir Şehir, 151/8-9)

$\checkmark$ "Kadını, gerçi, daima kendilerinden daha güçsüz görürler, ama bu güçsüzlüğe karşı duydukları acıma, çok defa, sevgi, saygı oluverir." (Benim Küçük Dostlarım, 113/13-16)

$\checkmark$ "Ailesi, kendisini bucakta okutabilecek güce sahipti. Fakat kız çocuğu olduğundan, onu uzaklara göndermekten yana değillerdi." (Göl Çocukları, 27/11-13)

\section{Dişil Cinsiyet İçin Küfür ve Argo ifadelerin Kullanılması}

$\checkmark$ “Ağzını bozar, 'Bire kahpe!.. Bir daha buraya gelirsen, senin bacaklarını ayırıım,' der." (Yalnız Efe, 94/7-9)

$\checkmark$ "Külhanbeyler alay ediyorlar sakallı bir bekçi, "Vallahi benim karıdan iyi" diye gülüyor. Bir dilenci Arap karısı: "Bunun kaltak karısının gözü kör olsun!" diye bağırıyordu." (Tanrı Misafiri, 93/6-9)

$\checkmark$ “Haspam düşmüş bayılmış." (İnci'nin Maceraları, 80/17)

$\checkmark$ "Oynak kız kılığındaki bu Keloğlan, nâmeyi alıp çekilmiş de geceyi beklemiş." (Keloğlan Masalları, 105/1-2) 
$\checkmark$ "Adamın karısı da oynak aşüftenin biri imiş. Kocasının bir yere gitmesini fırsat bilir, hovardasını içeri alırmış." (Keloğlan Masalları, 48/25-27)

$\checkmark$ "Bu deli kızın sözüyle, ne idiği belirsiz, numaracı, hırsız, şırııntı bir sokak kızını evime alacağım ha?" (Inci'nin Maceraları, 85/12-14)

$\checkmark$ "...bu kızı fazla hoppa ve züppe buluyordu, gayriihtiyarî, ondan ürküyordu." (Tanrı Misafiri, 148/6-7)

$\checkmark$ “Aman ağam, sen bana ne yüz ne de ikiyüz lira verdin. Anana mı verdin, oynaşına mı yedirdin?” (Keloğlan Masalları, 63/4-5)

$\checkmark$ "Eksik etek olmasaydın, ben siye (sana) gursuturdum! Ne fayda eksik eteksin!..." (Benim Küçük Dostlarım, 113/21-22)

$\checkmark$ “Hele şu küçük yosmaya bakın!" (Hep O Şarkı, 16/18)

$\checkmark$ "Bize eksik etek derler buralarda. Aklımız fazla ermez bizim." (Halime Kaptan, 123/15-16)

$\checkmark$ "Kapının önünden geçerken oynakça yürüyor." (Al'lı ile Fırfırı 2, 70/2)

$\checkmark$ "Ne yaptın be deli karı! diye haykırmış." (Sevdalı Bulut, 20/26)

$\checkmark$ "Müeyyet, yarı şaşkın yarı müstehzi bir tebessümle karısına baktı, Pakize'de şımarık bir neşe, tuhaf bir oynaklık vardı." (Tanrı Misafiri, 53/9-11)

$\checkmark$ "Romanlar ise bana, yoldan çıkan kadınların er geç büyük bir hüsrana uğradıklarını gösteriyordu." (Hep O Şarkı, 75/9-10)

$\checkmark$ "Vay anasını. Bir de aptal derler köylülere." (Inci'nin Maceraları, 96/1-2)

\section{Dişil Cinsiyetin Zihinsel Olarak Geri Görülmesi}

$\checkmark$ "Yalnız senden mi, benden de iyi bilirler..." (Yürekdede ile Padişah, 58/5)

$\checkmark$ "Bu budala şeylerin kadın ruhu üzerindeki tesiri malûm." (Tanrı Misafiri, 28/18-19)

$\checkmark$ "Karımın dediğine ne bakarsın, kadı efendi, benim karıcı̆ım safçadır, tahtaları eksikçedir." (Sevdalı Bulut, 22/3-4)

$\checkmark$ "Büyük kızını dokuz sene evvel kaçırmışlardı. Küçük kızı daha uslu akıllı çıkmış, evlenmiş barklanmıştı." (Seçme Hikâyeler, 5/13-15)

$\checkmark$ "Sığırtmacın karısı safçaymış." (Sevdalı Bulut, 18/2-3)

$\checkmark$ "Bu aptal karı azdırdı, kel kafamı da kızdırdı." (Keloğlan Masalları, 63/22-23)

$\checkmark$ "Karı kısmının her şeye aklı ermez... Hele senin gibi alık olursa!" (Tanrı Misafiri, 123/21-22)

$\checkmark$ "Halbuki kadın; çok sâf, çok görgüsüz bir mahlûk." (Tanrı Misafiri, 30/23-24)

$\checkmark$ "Bu inişte kadınca bir acemilik vardı, ama kimsenin gözüne çarpmamıştı karanlıkta." (Halime Kaptan, 100/22-23)

\section{Dişil Cinsiyetin Eril Cinsiyete Muhtaç Görülmesi}

$\checkmark$ "Hangi kocam? Ben dul bir kadınım..." (Tanrı Misafiri, 91/4)

$\checkmark$ "Meselâ üç ay evvel bir gece birkaç külhanbeyi sokakta bir yalnız kadın çevirmişler..." (Tanrı Misafiri, 102/3-5)

$\checkmark$ "Tek param pul olsun da, kızlarım dul olmasın!" (Evvel Zaman İçinde, 63/1-2)

$\checkmark$ "Başını alıp denize çıkan kadın için her şeyi söylerler... Hiçbiri umurumda değil!" (Halime Kaptan, 128/1-2)

$\checkmark$ "Fena bir kocaya düşmüştüm ve eğer mukadderse yirmi yaşıma basmadan boşanmış bir kadın olarak ana baba evinde kalacaktım. Ondan sonra beni artık kim alır." (Hep O Şarkı, 107/11-14)

$\checkmark$ "Erkeksiz kalınca karı milleti tez kötüler, solar beyim, dedi." (Yonca Kız, 36/9-10)

$\checkmark$ "Bir oğlum vardı, öldü; üç çocuğu benim başıma kaldı. Gelinimle onlara bakıyoruz. Erkeksizlik çok kötü." (Anılardan Öyküler 1, 78/24-26)

\section{Diğer}

$\checkmark$ "Tabiî... Doğrusu para için bu zevzek kocakarının kahrı çekilmez." (Tanrı Misafiri, 40/2-3)

$\checkmark$ "Hele çocuksuz kadınlara şeyhin mübarek nefesi iksir gibi tesir ederdi." (Tanrı Misafiri, 81/7-8)

$\checkmark$ "Nöbetçiler başladılar kadını dövmeye. "Kadın da dövülür müymüş, hem de ihtiyar bir kadın?" diyeceksiniz." (Sevdalı Bulut, 45/17-18) 
$\checkmark$ "Yeter!" diye haykırıncaya kadar döveceksin kızı." (Sevdalı Bulut, 63/2-3)

$\checkmark \quad$ "...gözlerini kapar, helal süt emmiş bir eş düşünür..." (Seçme Hikâyeler, 40/21-22) düşündüğü kadın

$\checkmark$ "Kösenin karısı da o sırada oturmuş, hovardasıyla yemek yiyormuş." (Keloğlan Masalları, 15/23)

$\checkmark$ "Bir zamanlar, öteki dünyada biz iki ortak kuma idik. Bu karga da bizim kocamızdı." (Keloğlan Masalları, 185/9-10)

$\checkmark$ "Bizim memlekette adamlar karıları kollarına bile takarlar." (Inci'nin Maceraları, 38/19-20)

$\checkmark$ "Şu savaş bir türlü bitmedi ki biz de kadınlığımızı bilip evde oturalım!.." (Halime Kaptan, 122/13-14)

$\checkmark \quad$ “...oğlan olsun dersen, iki tutam olmazsa, bir tutam akıl ister, yok kız olsun dersen, o da çok ister, az ister, her halde naz ister..." (Evvel Zaman İçinde, 124/18-20)

\section{Eril Cinsiyeti Yüceltici Söylemler}

Tablo 2.

Eril Cinsiyeti Yüceltici Söylemlerin Sıklık ve Yüzdeleri

\begin{tabular}{llc}
\hline & $f$ & $\%$ \\
\hline Zihinsel Olarak İleri & 9 & 21,95 \\
Güçlü ve Cesur & 7 & 17,07 \\
Evin Reisi Konumunda & 5 & 12,19 \\
Dişil Cinsiyetten Üstün & 6 & 14,63 \\
Dişil Cinsiyetten Daha Çok Hakka Sahip & 6 & 14,63 \\
Diğer & 8 & 19,51 \\
\hline Toplam & 41 & 100 \\
\hline
\end{tabular}

Bu bölümde, taranan eserler eril cinsiyeti yüceltici söylemler bağlamında incelenmiş ve 41 veriye ulaşıımıştır. Eril cinsiyeti yüceltici söylemler 6 alt başlık altında değerlendirilmiş ve Tablo 2'de gösterilmiştir. Eril cinsiyetin zihinsel olarak dişilden ileri görüldüğü $9(\% 21,95)$, güçlü ve cesur olarak nitelendirildiği $7(\% 17,07)$, evin reisi konumunda görüldüğü $5(\% 12,19)$, dişil cinsiyetten üstün bir cins olarak görüldüğü $6(\% 14,63)$, dişil cinsiyetten daha çok hakka sahip olarak görüldüğü $6(\% 14,63)$ ve bu kategorilere dâhil edilemeyen diğer $8(\% 19,51)$ veri saptanmıştır.

Taranan eserler eril cinsiyeti yüceltici söylemler bakımından incelendiğinde elde edilen veriler, Tablo 2' de belirtilen alt başlıklar halinde gruplanarak aşağıda listelenmiştir:

\section{Eril Cinsiyetin Zihinsel Olarak ileri Görülmesi}

$\checkmark$ "Yalnız senden mi, benden de iyi bilirler..." (Yürekdede ile Padişah, 58/5)

$\checkmark$ "Kimseye zararı olmayan bu insanların besili hayvanları, güzel kızları, çalışkan ve akıllı erkekleri vardı." (Yer Altında Bir Şehir, 39/20-21)

$\checkmark$ "Hemen o ülkenin yol yordam bilir, gün görmüş, sakal ağartmış bilginlerini toplamış." (Keloğlan Masalları, 106/6-7)

$\checkmark$ "Ama nasıl da belliydi onun erkeklerin bile zor başaracağı işlere girişeceği..." (Halime Kaptan, 118/11-12)

$\checkmark$ "Fakat babasını dinleyecekti; o en doğruyu bilir, söylerdi." (Gümüş Kanat, 140/2-3)

$\checkmark$ “Sazlıtepe'yi su bastığını sen gördün mü? -Ne ben, ne babam, ne dedem, ne de dedemin dedesi görmüş!.." (Bağrıyanık Ömer, 7/20-22)

$\checkmark$ "Nasıl olur, hanımefendiciğim? Bir kere paşa efendimizin fikrini almadan..." (Hep O Şarkı, 102/7-8)

$\checkmark$ "Şimdi ne yapmak fikrindesin? diye sordu. Ne emredersiniz efendim, dedim." (Hep O Şarkı, 104/15-16) 
$\checkmark \quad$ “...oğlan olsun dersen, iki tutam olmazsa, bir tutam akıl ister, yok kız olsun dersen, o da çok ister, az ister, her halde naz ister..." (Evvel Zaman İçinde, 124/18-20)

\section{Eril Cinsiyetin Güçlü ve Cesur Görülmesi}

$\checkmark$ "Nazlı bir erkek gibi silah kullanmasını biliyordu. Yine bir erkek kadar cesurdu." (Yer Altında Bir Şehir, 151/8-9)

$\checkmark$ "Insan ölürse erkek gibi ölür." (Yer Altında Bir Şehir, 65/22)

$\checkmark$ "Sakın ağlamak falan yok ha, dedi; erkek adam ağlamaz!" (Ötleğen Kuşu, 152/6-7)

$\checkmark$ "Kardeşi değil ya, ne olsa, bir erkek kadın yanında ağlamazdı." (Bağrıyanık Ömer, 64/23-24)

$\checkmark$ "iç̧inden "Bir erkek çocuğa ağlamak yakışmaz!" diyordu." (Gümüş Kanat, 161/12-13)

$\checkmark$ "Sen, çocuk gibi ağlamaya başladın. Erkeksin, metin ol..." (Tanrı Misafiri, 88/7-8)

$\checkmark$ "Selim'in annesi böyle sabahları yalnız başına mektebe giden hatta ortalık karardıktan sonra komşuya gelen erkek gibi çocuğa şaşıyordu." (87 Oğuz, 116/5-7)

\section{Eril Cinsiyetin Evin Reisi Olarak Görülmesi}

$\checkmark$ "Yengem dayımla ne soğuk konuşmuş, onu kapının önünde bırakıp gitmiş̧i. Evin erkeği böyle mi karşılanırdı?" (Yankılı Kayalar, 74/15-17)

$\checkmark$ "Çocukluk ve genç kızlık devirlerimle bu son bağlarımı muhafazaya, daha doğrusu halamın bir tâbiri veçhile "baba ocağını" büsbütün söndürmemeğe çalışırken..." (Hep O Şarkı, 144/9-11)

$\checkmark$ "O nasıl söz baba? Sen evin direğisin bugüne bugün." (Halime Kaptan, 13/16)

$\checkmark$ "Halime Abla bir şey diyemez. Bu evin erkeği benim.

...

Bu evin erkeği sensin ama askerliğini yapıp gelirsen." (Halime Kaptan, 67/14-17)

$\checkmark$ "Şehzade de gözünden gözüne emanet etmezken onu orada bırakıp "ver elini babam şehri!" der..." (Evvel Zaman İçinde, 84/19-21)

\section{Eril Cinsiyetin Dişil Cinsiyetten Üstün Görülmesi}

$\checkmark$ "Ah, şu bir erkek olsaydı! diye içini geçirdi." (Yalnız Efe, 121/19)

$\checkmark$ "...babam önde annemle ben arkada komşularımızın davetine bu kapıdan geçerek gitmiştik." (Hep O Şarkı, 23/13-14)

$\checkmark$ "Çocukluğumda babam pulu bana vermişti. Ben de oğluma verecektim." (Gümüş Kanat, 150/21-22)

$\checkmark$ "Öyle ki ỉbo "Erkek kızmış..." derken, başkasıyla ilgili kişisel yargılarını belirten birisinin gururuyla koltuklarını kabartıyor, hindi gibi kabarıyordu." (Gururlu Peri, 177/8-11)

$\checkmark$ "Halime gibi erkek karıların ne yapacağı hiç belli olmazdı." (Halime Kaptan, 48/19)

\section{Eril Cinsiyetin Dişil Cinsiyetten Daha Çok Hakka Sahip Görülmesi}

$\checkmark$ "Bu âlemin yabancısı değiliz. Biz de zamanında zamparalık ettik..." (Tanrı Misafiri, 56/15-16)

$\checkmark$ "Haydi caddeden gidip arabaların tozunu yutacağıma, kendi kendime bir kız âlemi yapayım dedim..." (Tanrı Misafiri, 76/23-25)

$\checkmark$ "Evet, ama erkekçe şeyler... Kadın ağzına yaraşmaz." (Tanrı Misafiri, 111/15-16)

$\checkmark$ "Meselâ haftanın birkaç gecesini dışarda geçirir. Seniha - Olabilir a. Erkektir bu; işi olur." (Tanrı Misafiri, 125/17-19)

$\checkmark$ "Birkaç karı almış, boşamış olabilirsin diye." (Bağrıyanık Ömer, 13/26)

$\checkmark$ "Ben bir memurum... Günde on saat erkekler gibi çalışıyorum. Onlar gibi sigara içmeye neden hakkım olmasın?" (Tanrı Misafiri, 148/29-31)

\section{Diğer}

$\checkmark \quad$ "Kamet getirdi. Kalın, erkek, mübarek bir sesle." (Yürekdede ile Padişah, 13/4-5)

$\checkmark$ "Ağabey... Sen erkeksin... Buna bir çare bul!..." (Tanrı Misafiri, 88/22-23) 
$\checkmark$ "Kundaktaki kardeşimi de bana bırakıyor. Öyle kızıyorum ki. Boğasım geliyor. Ben kız mıyım?" (Inci'nin Maceraları, 68/11-13)

$\checkmark$ "Şube reisi demiş ki gelsin teslim olsun. Ona erkek sözü. Bir keresine bağışlarım." (Halime Kaptan, 69/1-2)

$\checkmark$ "Hâlbuki şimdi kararını erkekçe bir tavır ve sesle ona söylüyordu." (Gümüş Kanat, 39/2-3)

$\checkmark$ "Eh, oğul yok, uşak yok; koç yok, koçak yok; geçinmeyecek ne başları var!" (Evvel Zaman İçinde, 156/11-12)

$\checkmark$ "Bakır Efe dövmekle değil, öldürse Emine'den hiddetini alamayacaktı." (Bağrıyanık Ömer, 24/14-15)

$\checkmark$ "Kuşların, hayvanların canını yakmak hiç güzel değil ama el eline bakmaya, köleliğe dayanamaz adam olan." (Al'ı ile Fırfırı 2, 67/4-6)

\section{Dişil ve Eril Cinsiyetin Günlük Yaşamdaki Rolleri}

Tablo 3.

Dişil ve Eril Cinsiyetin Günlük Yaşamdaki Rollerinin Sıklık ve Yüzdeleri

\begin{tabular}{lcccc}
\hline & Kadın (f) & $\%$ & Erkek (f) & $\%$ \\
\hline Mutfak İşleri & 83 & 97,64 & 2 & 85 \\
Evin Düzeni & 21 & 95,45 & 1 & 22 \\
Evin Temizlik İşleri & 21 & 95,45 & 1 & 22 \\
Soba- Ocak Yakımı & 8 & 100 & - & 8 \\
Ahır-Kümes ve Bahçe İşleri & 14 & 77,77 & 4 & 18 \\
Örgü-Dikiş İşleri & 8 & 100 & - & 8 \\
Çocuğun İhtiyaçlarını Karşılama & 45 & 76,27 & 14 & 59 \\
Çocuğun Eğitimi ile İlgilenme & 5 & 41,66 & 7 & 12 \\
Diğer & 13 & 25 & 39 & 52 \\
\hline
\end{tabular}

Bu bölümde, taranan eserlerden elde edilen veriler eril ve dişil cinsiyetin günlük yaşamdaki rolleri bağlamında ele alınmıştır. Günlük yaşamdaki roller başlığı altında eril ve dişil cinsiyetin gün içinde nelerle meşgul olduğu, vaktini nasıl geçirdiği, aile içindeki yaşantıya ne denli katkıda bulunduğu, çocuğun intiyaçları ve eğitimi ile ne ölçüde ilgilendiği gibi kıstaslar ele alınmış ve ulaşılan veriler gruplandırılmıştır.

Taranan eserlerden elde edilen veriler yukarıda anlatılanları destekler niteliktedir. Veriler mutfak işlerini hangi cinsin yaptığının tespiti açısından değerlendirildiğinde toplam 85 (\%100) işten 83'ünü (\%97,64'ünü) kadının yaptığı görülmüştür. Geriye kalan $2(\% 2,35)$ işi erkek yapmıştır. Fakat metin içi bağlamdan anlaşıldığı üzere o erkeklerin bu işi sürekli yapmadığı anlaşılmaktadır. Ya erkek kadına yardım eden roldedir ya da nadiren mutfağa giren bir imaj sergilemektedir. Tüm bu verilerden anlaşılan, günlük yaşamda kadın tüm mutfak işlerinden sorumlu aile bireyidir. Eşi, çocukları ve varsa evin büyükleri tüm mutfak işlerini kadından beklemekte ve bunu kadının sorumluluğu olarak görmektedir.

Taranan eserlerde evin düzeni başlığı altında değerlendirilebilecek 22 (\%100) veri tespit edilmiştir. Evin düzeni ile ilgili sorumlulukları üstüne alan cinsin dişil cinsiyet olduğu görülmüştür. Toplam işlerin $\% 95,45^{\prime}$ ini kadın yapmaktadır. Sadece $1(\% 4,54)$ örnekte erkeğin de sorumluluk aldığı tespit edilmiştir. Bu örnekte erkeğin sorumluluk almasının sebebi daha çok ev dışı bir sorumluluk olmasından kaynaklanabilir. Kışlık odunun ve kömürün alınması evin düzenini sağlamaya yönelik bir iştir fakat ev dışında icra edilir.

Veriler, evin temizlik işlerini hangi cinsin yaptığına yönelik incelendiğinde $21(\% 95,45)$ işin kadın, $1(\% 4,54)$ işin erkek tarafından yapıldığı görülmüştür. Erkek tarafından yapıldığını gösteren 1 işin ise tam olarak ne olduğu anlaşılamamaktadır. İlgili cümlede 'köyün tüm insanları' ifadesinin geçmesi ve bu ifadenin erkeği de kapsaması dolayısıyla evin temizlik işine eril cinsin de katkısı olduğu düşünülmüştür. 
Günlük yaşamda ev içi roller kapsamında değerlendirilen soba-ocak yakımı ve örgü-dikiş işlerini hangi cinsin üstlendiğine yönelik Tablo 3'e bakıldığında her biri için toplam 8 (\%100) verinin hepsinin dişil cinsi gösterdiği görülmektedir.

Tablo 3, günlük yaşamda ev dışı roller kapsamında ahır-kümes ve bahçe işlerini hangi cinsin yaptığı bağlamında incelendiğinde toplamda 18 (\%100) işin 14'ünü (\%77,77'sini) kadının, 4'ünü (\%22,22'sini) erkeğin yaptığı dikkati çekmektedir.

Dişil ve eril cinsiyetin günlük yaşamdaki rollerinden belki de en önemlisi çocuklarına karşı üstlendikleri sorumluluklardır. Söz konusu bir insan ve onun gelişimi olduğunda diğer tüm işlerin anlamını yitirmesi beklenir. Tablo 3'te çocuğun ihtiyaçlarını 45 veri, \%76,27 oranla kadının karşıladığı görülmektedir. Çocuğun eğitimi söz konusu olduğunda ise erkeğin daha etkin bir rol çizdiği görülmektedir. Çocuğun eğitimi ile ilgili, toplam 12 (\%100) sorumluktan 5'ini $(\% 41,66)$ kadın, 7'sini (\%58,33'ünü) erkeğin üstlendiği görülmüştür.

Tablo 3'te, yukarıda sayılan rollerin dışında kalan aile içi diğer sorumluklar kapsamında 52 (\%100) adet veriden $13^{\prime} u ̈$ (\%25'i) kadını, 39'u (\%75'i) erkeği gösterir.

Tablo 4.

Dişil ve Eril Cinsiyetin Günlük Yaşamdaki Rollerinin Toplam Sıklık ve Yüzdeleri

\begin{tabular}{lcc} 
& $f$ & $\%$ \\
\hline Kadın & 218 & 76,22 \\
Erkek & 68 & 23,77 \\
\hline Toplam & 286 & 100 \\
\hline
\end{tabular}

Tablo 4'te dişil ve eril cinsiyetin günlük yaşamdaki rollerinin toplam sıkılık ve yüzdeleri verilmiştir. Taranan eserlerden aile içi roller kapsamında 286 (\%100) veri tespit edilmiştir. Dişil cinsiyetin $218(\% 76,22)$ veri ile günlük yaşamda aile içi sorumluluk kapsamında daha etkin rol oynadığı dikkati çekmiştir. Eril cinsiyete ise bu bağlamda sadece $68(\% 23,77)$ kez rastlanmıştır.

Taranan eserler dişil ve eril cinsiyetin günlük yaşamdaki rolleri bakımından incelendiğinde elde edilen veriler, Tablo 3'te belirtilen alt başlıklar halinde sınıflandırımıştır:

\section{Mutfak işleri}

$\checkmark$ "Ve Ayşe Nine çorbayı ocağa koydu." (Yürekdede ile Padişah, 13/16)

$\checkmark$ "Şimdi kızanlar eski yıllarda olduğu gibi, "Ana, ana gı, ekmek!" diye vızıldıyorlardı." (Yonca Kız, $12 / 22-23)$

$\checkmark$ "Çamaşır yuğduğu, sökük diktiği, aş pişirdiği sıra Yonca Kız, Ayşe'yle Aysel’i oyalıyordu." (Yonca Kız, 66/2-4)

$\checkmark$ "Kezban gelin, misafir odasına sakızlar gibi temiz yataklar yaydı. Onlar için güzel yemekler pişirdi." (Yonca Kız, 181/26-27)

$\checkmark$ "Kadınlar taştan ocaklarda ateş yakarak fasulye, yumurta haşlıyorlar, kahveler çaylar pişiriyorlardı. Erkekler tef darbuka çalıyorlar, el çırpıyorlar, oyun bilenleri ortaya çıkıp bahriye çiftetellisi, harmandalı, avaramu oynuyorlardı." (Yonca Kız, 69/6-10)

$\checkmark$ "Nazlı da misafirleri içeride karşılamıştı. Ellerini sıkıp hatırlarını sorduktan sonra yemeği hazırlamaya gitti. (Yer Altında Bir Şehir, 92/31-32)

$\checkmark$ "Anamdan gördüğüm gibi bir çorba pişirdim." (Yankılı Kayalar, 27/2)

$\checkmark$ "Şimdi kahve yapma, dedi, misafirlerle içerim." (Yalnız Efe, 108/3)

$\checkmark$ "Sonçiçek okuldan dönmemişti henüz. Karısı ise mutfaktaydı." (Uç Minik Serçem, 39/12)

$\checkmark$ "Hele gözünü seveyim bal yanaklım. Bir üzüm şerbeti yap da getir." (Tanrı Misafiri, 22/23-24)

$\checkmark$ "Madam, kapının önünde balık pişiriyordu." (Tanrı Misafiri, 144/23-24)

$\checkmark$ "Böyle gözüme uyku girmediği geceler öteki anam kalkar, bana baklava börek pişirirdi. Ben de onları yer yemez uykuya dalıverirdim." (Sevdalı Bulut, 93/3-5)

$\checkmark$ "Demir bir sacayağının önünde çömeliyor, odunları tutuşturuyor ve üzerinde genellikle tarhana çorbasının kazanı kaynıyor." (Serçekuş, 26/18-20) 
$\checkmark$ “Çünkü annemin sarmaladığı yemek çıkınını babama götürmek, bana ayrı bir güven verirdi." (Ötleğen Kuşu, 9/11-13)

$\checkmark$ "Annem kalkmış, yatağı toplanmış, avluda yayık dövüyor olmalı." (Ötleğen Kuşu, 10/10-11)

$\checkmark$ "Babaannem size köfte yaptı, dedi." (Ötleğen Kuşu, 14/7)

$\checkmark$ "Yemekten sonra, annem sofrayı kaldıırken, çocuklar, ansızın ağulu örümcek sokmuş gibi bir yaygara kopardılar." (Ötleğen Kuşu, 36/3-4)

$\checkmark$ "Hayri'nin yemeğini hazırlayayım, ben hepsini yaparım." (Kuklacı, 14/20-21)

$\checkmark$ "Annesi, mutfakta kabak kızartıyordu." (Inci'nin Maceraları, 19/4)

$\checkmark$ "Gene kim bilir bize ne tatlı yemekler pişireceksin." (Inci'nin Maceraları, 15/2-3)

$\checkmark$ "Nurhan'ın sarı, sinirli, son derece zayıf ablası, mutfakta yemek masasını hazırlıyordu." (İnci'nin Maceraları, 77/9-11)

$\checkmark$ "Cici annem ekmeğime tereyağıyla reçel sürüyor." (Innci'nin Maceraları, 62/9-10)

$\checkmark$ "Evet, şimdi yiyeceğiniz kaymakları, börekleri de ben pişirdim." (Havaya Uçan At, 95/18-19)

$\checkmark$ "Sonra Süzen kocasının paltosunu, şapkasını alırdı ve hemen mutfağa koşardı." (Gümüş Kanat, 20/25-27)

$\checkmark$ "Gözlerinde bir parıltı, yüzünde bir gülümseme, dudaklarında içe işleyen sesiyle bir şarkı hiç eksilmezdi. Temizlik yaparken, yemek pişirirken, dikiş dikerken hep böyleydi." (Gümüş Kanat, 16/16-19)

$\checkmark$ "Günlerden bir gün, Hılı çalı çırpı toplar; Dılı da tandır yakıp, ekmek yapar." (Evvel Zaman İçinde, $122 / 18-19)$

$\checkmark$ "O gece yemekten sonra her zamanki gibi annesine yardım etti. Annesi, bulaşıkları bitirdi." (Gümüş Kanat, 168/24-25)

$\checkmark$ "Annem, birkaç günden beri söyleyip durduğu kandil çöreklerini yapıp komşulara dağıtacaktı." (Anılardan Öyküler 2, 28/3-4)

$\checkmark$ "Karıcığım, biz açız, yemek pişir de yiyelim." (Al'ı ile Fırfırı 2, 24/8)

$\checkmark$ "Annem, başını sallayarak güldü ve mutfağa girdi." (Anılardan Öyküler 1, 100/15)

$\checkmark$ "Annesi dışarı çıkmış, bu ilk günün şerefine ona zengin bir yemek tası hazırlıyordu." (87 Oğuz, 13/26-27)

$\checkmark$ "Kaç kere annesi ona bir yiyecek veremediği için elini kolunu sallaya sallaya mektebe gitmişti" (87 Oğuz, 13/8-10)

$\checkmark$ "Annesi ne koymuştu acaba? Peynir mi, zeytin mi, yumurta mı, yoksa helva mı?" (87 Oğuz, 48/12-13)

$\checkmark$ "Hatta daha iyisi, bu salata ile sen meşgul ol... Aydın'da iken sen ne güzel yapardın." (Tanrı Misafiri, 48/12-13)

$\checkmark$ "Annem, babam avlunun ortasındaki büyük ocakta pekmez kaynatırken biz iki kız, bu kuru dalların arasında eğlencelere dalardık." (Anılardan Öyküler 1, 49/5-7)

\section{Evin Düzeni}

$\checkmark$ "Durma, Gonca Ana, çık şu kerevete, yatakları yapıver!" (Yonca Kız, 22/3-4)

$\checkmark$ "Caminin karşısındaki küçük kahvede oturan iri yarı, siyaha yakın esmer, sakallı yüzüyle, heybetli babasını, devamlı iş gören, yemek pişiren, çamaşır yıkayan anasını hatırladı." (Bir Küçük Osmancık Vardı, 55/22-25)

$\checkmark$ "Henüz on altı yaşında olduğu hâlde bütün evin işi -yemek ve çocuklar dâhil- onun üstünde idi." (Benim Küçük Dostlarım, 94/27-28)

$\checkmark$ "Kezban gelin, misafir odasına sakızlar gibi temiz yataklar yaydı. Onlar için güzel yemekler pişirdi." (Yonca Kız, 181/26-27)

$\checkmark$ "“Emret derviş baba," dedi, "görülecek işin varsa göreyim. Karnın açsa tarhana pişireyim sana. Uykun geldiyse döşek sereyim altına." (Sevdalı Bulut, 24/30-32)

$\checkmark$ "Annem kalkmış, yatağı toplanmış, avluda yayık dövüyor olmalı." (Ötleğen Kuşu, 10/10-11)

$\checkmark$ "...karısına demiş ki:

$\checkmark$-Bugün evi bir güzel düzene koyar, hazırlarsın. Bir iki kap da yemek yaparsın." (Keloğlan Masalları, 55/6-8) 
$\checkmark$ "Bir gün sığırtmacın karısı dereden su almaya gitmiş." (Sevdalı Bulut, 18/5)

$\checkmark$ "Köyün insanları, kadınlar ve çocuklar da dâhil olmak üzere evlerde, ahırlarda ve tarlalarda işlerine dalmışlardı." (Serçekuş, 55/5-7)

$\checkmark$ "Üvey anam pufla bir yatak sermiş, yatağı kabartmıştı." (Seçme Hikâyeler, 48/30-31)

$\checkmark$ "Ev kadınlığının bütün mes'uliyetini, o yalnız bu hususta yüklenmiş bulunuyordu ve işte, sanırım, bütün bu zahmetlerinin acısını çıkarmak içindir ki, alabildiğine can besliyordu." (Hep O Şarkı, 55/12-15)

$\checkmark$ "Emine hem evine hem çocuğuna bakıyordu." (Havaya Uçan At, 70/4-5)

$\checkmark$ "Babası, zaten evde hiç durmadan didinen, evin büyük işlerini bir makine düzeniyle yerine getiren karııının bir de dışarıda işe gitmesine bir türlü razı olmak istememişti." (Gümüş Kanat, 16/2-5)

$\checkmark$ "Fatma Hanım, ev işlerini henüz bitirmişti." (Bir Küçük Osmancık Vardı, 5/10)

$\checkmark$ "Çok nazik olan Müdür, karısı kasabada bulunmadığından beni evinde misafir edemediği için son derece üzüldü." (Domaniç Dağlarının Yolcusu, 42/12-14)

$\checkmark$ "Yemek için lazım olursa, perdeyi sıkıca kapatıp mutfak lambasını yak." (Bir Küçük Osmancık Vardı, 32/15-17)

$\checkmark$ "Oğuz giyinirken annesi onun yatağını kaldırıp yüklüğe koydu." (87 Oğuz, 123/12-13)

$\checkmark$ "Haydi kızım, konuklarımızın yataklarını yap." (Al'ı ile Fırfırı 2, 173/4)

$\checkmark$ "Elektrik kısıtlaması olduğu için annem, mumu ve kibriti masanın üzerine hazırlamıştı." (Anılardan Öyküler 2, 24/3-5)

\section{Evin Temizlik işleri}

$\checkmark$ "Çamaşır yuğduğu, sökük diktiği, aş pişirdiği sıra Yonca Kız, Ayşe'yle Aysel'i oyalıyordu." (Yonca $\mathrm{KIz}, 66 / 2-4)$

$\checkmark$ "Belki lokma ya da aşure yapılırken yardım etmeye, belki de temizliğe gitmiş olacaktı yine... Hatçe Nine de alacakaranlık odada, bazlama yaptığı saçı kaldırmış, ocağı söndürüyordu." (Ötleğen Kuşu, 45/18-21)

$\checkmark \quad$ "Gözlerinde bir parıltı, yüzünde bir gülümseme, dudaklarında içe işleyen sesiyle bir şarkı hiç eksilmezdi. Temizlik yaparken, yemek pişirirken, dikiş dikerken hep böyleydi." (Gümüş Kanat, 16/16-19)

$\checkmark$ "Caminin karşısındaki küçük kahvede oturan iri yarı, siyaha yakın esmer, sakallı yüzüyle, heybetli babasını, devamlı iş gören, yemek pişiren, çamaşır yıkayan anasını hatırladı." (Bir Küçük Osmancık Vardı, 55/22-25)

$\checkmark$ “Önümde önlük, elimde su kovası, yahut süpürge ile kendimi gördükçe hem kızıyor, hem de kırk yaşından sonra alâimisema altından geçmiş gibi hanım kız oluşuma gülüyordum." (Tanrı Misafiri, 91/31-34)

$\checkmark$ "Suyun başında çamaşırlarını döven kalın çıplak baldırlı kadınları, evinin önünde ezeli çoraplarını ören hiddetli kızları..." (Yalnız Efe, 7/8-10)

$\checkmark$ "Ayşe hayatlığı süpürüyor; Hasan sedirin altından karpuz çıkarıp üzerine oturmuş;

-Deh... Deh... Deh!.. diye yürütmeye çalışıyordu." (Ötleğen Kuşu, 13/3-5)

$\checkmark$ "İnci, usulcacık, "Çamaşıra daldı galiba," dedi ve hemen komutanlığını takındı." (İnci'nin Maceraları, 51/1-2)

$\checkmark \quad$ "...annemin dadımla birlikte bazı büyük temizlik işlerine bakmakla meşgul olduğu zamanlara rastgetirirdim." (Hep O Şarkı, 38/17-19)

$\checkmark$ "Hayır, hayır... dedi. Ev işlerinde bana yardım etti." (Gümüş Kanat, 154/6)

$\checkmark$ "Buna bütün ev halkının kadınları ve Fatma Hanımın kendisi de sevinmişti. İşlerin üstüne yıkılacağından korkan gelinle annesi rahat bir nefes almışlar." (Kuklacı, 22/16-18)

$\checkmark$ "Çok sevdiğim ağabeyim bana, -Melek, şu gömleğimim yıkar mısın, dedi." (Anılardan Öyküler 2, 73/17-19)

$\checkmark$ "Bir iki kadın, çamurlu derede, ellerindeki bezleri taşlara çarpa çarpa çamaşır yıkıyor." (Domaniç Dağlarının Yolcusu, 70/9-10) 
$\checkmark \quad$ "Bir kızım var. Kuyu temizlemesini bilir o. Yarın, göndereyim, temizleyiversin." (Al'lı ile Fırfırı 2, 176/8-9)

$\checkmark$ "Evimizde bayram temizliği yapıyorduk. Annem, bayram temizliğini öyle yapardı ki!.." (Anılardan Öyküler 1, 96/15-16)

$\checkmark$ “Anne, öbür gün bir misafirim gelecek... Ortalı̆̆ı sil, süpür emi?” (87 Oğuz, 122/2-3)

$\checkmark$ "Köyün insanları, kadınlar ve çocuklar da dâhil olmak üzere evlerde, ahırlarda ve tarlalarda işlerine dalmışlardı." (Serçekuş, 55/5-7)

\section{Soba-Ocak Yakımı}

$\checkmark$ "Nenesi bunun halinden âciz kalıp, ocağı yakmaya, çorbayı pişirip katarmaya yetişemez olmuş." (Keloğlan Masalları, 7/6-8)

$\checkmark$ "Elif Teyze de bulaşık yıkamak için evin önündeki ocağa, bu kuru dallardan koyuyordu." (Anılardan Öyküler 1, 50/12-14)

$\checkmark$ "Bu dumanlar evin gelinleri veya kızları tarafından ocakların içinde yakılan ateşlerden çıkıyor." (Serçekuş, 26/16-18)

$\checkmark$ "Demir bir sacayağının önünde çömeliyor, odunları tutuşturuyor ve üzerinde genellikle tarhana çorbasının kazanı kaynıyor." (Serçekuş, 26/18-20)

$\checkmark$ "Süzen, sobaya iki odun atmak üzere kalktı." (Gümüş Kanat, 116/13-14)

$\checkmark$ "...Anasının içini hazırlayıp kapısını açık bıraktığı saç sobadaki çırayı tutuşturmakta gecikmedi." (Gururlu Peri, 24/2-4)

$\checkmark$ "Annesi yatağın bir ucuna oturmuş, önündeki mangalı eşeliyordu. Sacağının üstünde mavi çay ibriği kaynıyordu. Beyaz entarisiyle yatağın içinde ilk cigarasını içen babası Oğuz’u bir kere süzdü:

-Bugün mektep açılıyormuş öyle mi?" (87 Oğuz, 15/2-6)

$\checkmark$ "Günlerden bir gün, Hılı çalı çırpı toplar; Dılı da tandır yakıp, ekmek yapar." (Evvel Zaman Iç̧inde, 122/18-19)

\section{Ahır-Kümes ve Bahçe İşleri}

$\checkmark$ "Anam ineklerimizi sağar, peynirimizi, yağımızı ve yoğurdumuzu yapar. Tavuklarımızı kuluçkaya yatırır." (Yankılı Kayalar, 7/19-21)

$\checkmark$ "Kadınlar da yetişkin kızlarla beraber tarlalarda, bahçelerde erkeklerle beraber çalışıp duruyor ve öğle yemeği için götürülmüş azıklarının başına bir hal gelmesin diye sık sık bakışlarını o yöne çeviriyorlar." (Serçekuş, 57/10-13)

$\checkmark$ "Adam aç olduğundan, kadın ocağa yağ koymuş da, kümesten yumurta almaya gitmiş. Bu adam da yorgun olduğundan, yemek pişene kadar köşeye yaslanmış, uyuyuvermiş." (Keloğlan Masalları, 48/28-31)

$\checkmark$ "Köyün insanları, kadınlar ve çocuklar da dâhil olmak üzere evlerde, ahırlarda ve tarlalarda işlerine dalmışlardı." (Serçekuş, 55/5-7)

$\checkmark$ "Kezban sebepsiz bir üzüntü içinde sıkılıyordu. Ahırı temizledi. Biraz çamaşır yıkadı. Sonra, tahtaları sildi." (Yalnız Efe, 123/1-3)

$\checkmark$ "Akşamleyin kadıncağız, ineğini sağmaya giderken..." (Sevdalı Bulut, 99/25)

$\checkmark$ "Dönerlerken Kezban ahıra uğramak için ayrıldı. Babası, -Yarın erken gideceğim! Atı erken hazırla! dedi." (Yalnız Efe, 121/11-13)

$\checkmark$ "Ahırdaki folluklardan yumurtaları topladı." (Yalnız Efe, 124/10-11)

$\checkmark$ "Anam çok çalışıyordu. Toprak işiyle, ineklerle uğraşıyordu. Bu işlerden boş kaldıkça da yün çoraplar örüyordu." (Yankılı Kayalar, 18/1-3)

$\checkmark$ "Ben evde, bahçede, bu ihtiyar halimle uğraşıyorum. Yün eğiriyorum, çorap örüyorum. Tavuktu, yumurtaydı, ne denkleştirirsem pazarda satıyorum." (Keloğlan Masalları, 166/16-19)

$\checkmark$ "Sabahları babası ile beraber evlerinden çıkarlarken annesi onları uğurlayacak ve sonra bahçesi ile uğraşacaktı." (Gümüş Kanat, 176/10-12) 
$\checkmark$ "Selçuk'un annesi Şaziye; tarlayla, hayvanlarla uğraşırken, babası Çetin de çok kez büyük toprak sahiplerinin buyruğunda ırgatlık yapıyordu. Ailesini geçindirmek için buna zorunluydu." (Göl Çocukları, 24/13-17)

$\checkmark \quad$ "Annem titizleniyor, -Ahıra girmeyin, çamaşırlarınız at kokuyor..." (Anılardan Öyküler 2, 18/6-7)

$\checkmark$ "Ellerinde orağı, çapası, arkasında çocuğu, omzunda testisiyle kadınlar, loş yollardan dönüyor." (Domaniç Dağlarının Yolcusu, 58/7-8)

$\checkmark$ "Günlerden bir gün, Hılı çalı çırpı toplar; Dılı da tandır yakıp, ekmek yapar." (Evvel Zaman Iç̧inde, 122/18-19)

$\checkmark$ "Bir gün, çift sürmekten dönen iki adam, bu çocukların aşık oynamalarına bakıyorlar." (Al'ı ile Fırfırı 2, 68/23-25)

$\checkmark$ “Kadınlar da yetişkin kızlarla beraber tarlalarda, bahçelerde erkeklerle beraber çalışıp duruyor ve öğle yemeği için götürülmüş azıklarının başına bir hal gelmesin diye sık sık bakışlarını o yöne çeviriyorlar." (Serçekuş, 57/10-13)

$\checkmark$ "Babam aşı yaptıkça, parmak büyüklüğünde zeytinler, sulu sulu armutlar veriyorlar..." (Ötleğen Kuşu, 7/26-27)

\section{Örgü-Dikiş işleri}

$\checkmark$ "Çamaşır yuğduğu, sökük diktiği, aş pişirdiği sıra Yonca Kız, Ayşe'yle Aysel'i oyalıyordu." (Yonca Kız, 66/2-4)

$\checkmark \quad$ "Gözlerinde bir parıltı, yüzünde bir gülümseme, dudaklarında içe işleyen sesiyle bir şarkı hiç eksilmezdi. Temizlik yaparken, yemek pişirirken, dikiş dikerken hep böyleydi." (Gümüş Kanat, 16/16-19)

$\checkmark$ "Elif abla, taşlıkta, idare kandilinin önünde, sökük dikiyordu." (Tanrı Misafiri, 20/19-20)

$\checkmark$ "Osman baba o gece bir iki kız daha buldu. Onlara file ördürdü." (Yer Altında Bir Şehir, 131/1415)

$\checkmark$ "Annem, oturma odasında bir yere ilişmiş, sessizce söküklerimizi dikiyordu." (Ötleğen Kuşu, 100/5-6)

$\checkmark$ "Akşam babasının eskilerinden Oğuz'a bir pantolon diktim." (87 Oğuz, 113/19)

$\checkmark$ "Fakat bütün bu yamalar "çok dikkatli ve titreyen bir ana eliyle yapıldım" diyor gibiydi." (87 Oğuz, 125/8-10)

$\checkmark$ "Annem, arka bahçede, babamın iş tulumunu yamıyordu." (Anılardan Öyküler 1, 44/22-23)

\section{Çocuğun ihtiyaçlarını Karşılama}

$\checkmark$ "Şimdi kızanlar eski yıllarda olduğu gibi, "Ana, ana gı, ekmek!" diye vızıldıyorlardı." (Yonca Kız, $12 / 22-23)$

$\checkmark$ "Henüz on altı yaşında olduğu hâlde bütün evin işi -yemek ve çocuklar dâhil- onun üstünde idi." (Benim Küçük Dostlarım, 94/27-28)

$\checkmark$ "Emine hem evine hem çocuğuna bakıyordu." (Havaya Uçan At, 70/4-5)

$\checkmark$ "Kötü olsa anaları onca kızın saçını örer miydi?" (Yonca Kız, 47/15-16)

$\checkmark$ “"Durma kaldır, geydir kıza yeni urbalarını!” dedi, Mehmet." (Yonca Kız, 51/1-2)

$\checkmark$ "Anam Hatice' nin saçlarını tarıyordu." (Yankılı Kayalar, 31/24)

$\checkmark$ "Anası: "Ninni söyleyelim çocuğa" diyor." (Sevdalı Bulut, 16/2-3)

$\checkmark$ "Keloğlan'ın anası hem bu sözleri söylermiş, hem de bir yandan ağlar, bir yandan evladına yol hazırlığı görürmüş.” (Sevdalı Bulut, 91/15-16)

$\checkmark$ "Uyuyorlar mı diye merak edip, kapıdan başını uzatan annemi güldürdü." (Ötleğen Kuşu, 93/17-18)

$\checkmark \quad$ “...annem, pembecik pembecik sivilce belirtilerinden, onun kızamık olduğunu anladı." (Ötleğen Kuşu, 126/1-2)

$\checkmark$ "Yatmadan önce, anam bana elekle dereden taze su getirirdi de öyle uyurdum..." (Keloğlan Masalları, 32/13-14) 
$\checkmark$ "Marizleyelim ama, annem beni her zaman sokağa bırakmaz ki..." (Inci'nin Maceraları, 68/5-6)

$\checkmark$ "Dadım, büyük bir itina ile saçlarımı örerdi." (Hep O Şarkı, 43/20)

$\checkmark$ "Kemal, pencereden dala uzanırken kulağında annesinin sesi çınladı: Şeytan çeker Kemal! Düşersin!" (Gümüş Kanat, 10/15-16)

$\checkmark$ "Anası onların bakımında güçlük çekiyor, "Sen de bana hiç yardımcı olmuyorsun..." diye yakınıyordu ikide bir." (Gururlu Peri, 37/3-4)

$\checkmark$ "Duygu, annesinden izin isteyerek dürbünü evde asılı olduğu yerden aldı ve arkadaşının yanına geldi." (Göl Çocukları, 70/17-19)

$\checkmark$ "Her ikisi de annelerinden 'şöyle bir dolaşmak için' izin aldılar." (Göl Çocukları, 53/17-18)

$\checkmark$ "Bırak elinden onu! Terleyip hasta olacaksın." (Falaka, 32/5)

$\checkmark$ "Ben içmiyordum. Annemin sözlerini pek sayardım." (Falaka, 38/13-14)

$\checkmark$ "Çoğu babalar baca tütünü; ana güder kuzuyu..." (Evvel Zaman İçinde, 22/21)

$\checkmark$ "Anneler çocuklarının başlarını, kollarını pencere kenarlarından içeriye çektiler." (Domaniç Dağlarının Yolcusu, 22/15-16)

$\checkmark$ "Kitaplığın yanına giderken öğle uykusuna yatırdığı Osman'a gözü ilişti." (Bir Küçük Osmancık Vardı, 5/12-13)

$\checkmark$ "Annem, başucumda duruyor, her yer ilaç kokuyordu." (Anılardan Öyküler 2, 64/23)

$\checkmark$ "Annem, hiçbir komşu çocuğunu eve almadığı, beni de sokağa bırakmadığı için, günlerimi bu minik gözlü doldururdu." (Anılardan Öyküler 1, 95/25-27)

$\checkmark$ "Yanakların çamur içinde, şu cebini annene dik deseydin dikmez miydi?" (87 Oğuz, 67/1-2)

$\checkmark$ "Ben iş görür iken beşiğini salladığı zamanlar bilem olurdu." (Gururlu Peri, 62/21-22)

$\checkmark$ "Babam merhum beni bu gibi eğlencelere götürürdü." (Kuklacı, 28/10-11)

$\checkmark$ "Babam, her bayram sabahı bize gevrek alırdı." (Anılardan Öyküler 2, 91/10-11)

$\checkmark$ "Sonra Selami Çavuş'a çocukların babalarını çağırmalarını söyledi." (Göl Çocukları, 63/17-19)

$\checkmark$ "Dördüncü sınıfı 'pekiyi' ile geçtiği için, babasının üç gün önce satın aldığı..." (İnci'nin Maceraları, 57/1-2)

$\checkmark$ "Babandan para geldi çocuğum. Sana yemek hazırladım." (Tanrı Misafiri, 107/18-19)

$\checkmark$ "En sonunda babam pembe yel değirmenini aldı bana." (Anılardan Öyküler 1, 14/1)

$\checkmark$ "Ali ve Galip akşamüzeri yorgun argın geldiler. Karısı sofrayı hazırlarken, Ali de çocuklarıyla hasret giderdi." (Bir Küçük Osmancık Vardı, 58/14-16)

$\checkmark$ "Babamın sesini duydum:

-Haydi, herkes kahvaltıya!" (Anılardan Öyküler 2, 91/8-9)

\section{Çocuğun Eğitimi ile ilgilenme}

$\checkmark$ "Anan rahmetli, seni gül yerine koyup da göğsünde taşıyacağına, önüne iş verip de parmaklarını işletseydi, ellerin her işe yatardı şimdi..." (Evvel Zaman İçinde, 151/7-10)

$\checkmark$ "Oğuz, böyle çocuğunu mektebe kadar götürüp getiren, kitabı ile, okuması ile uğraşan analara şaşıyordu." (87 Oğuz, 31/13-14)

$\checkmark$ "Gerçi dövmezdi ama gözümü iyice yıldırmıştı. Ondan korkardım." (Falaka, 9/21-22)

$\checkmark$ "Annene söyle, sana bizim okuldakiler gibi kitap alsın." (Falaka, 18/7-8)

$\checkmark$ "Annesi yatağın bir ucuna oturmuş, önündeki mangalı eşeliyordu. Sacağının üstünde mavi çay ibriği kaynıyordu. Beyaz entarisiyle yatağın içinde ilk cigarasını içen babası Oğuz'u bir kere süzdü:

-Bugün mektep açılıyormuş öyle mi?" (87 Oğuz, 15/2-6)

$\checkmark$ "Babam, bir hafta önce, beni evimize yakın olan okula yazdırdı." (Anılardan Öyküler 1, 88/2-3)

$\checkmark$ "Olayı babam duyunca, hemen okula koştu. Öğretmenlerimle konuştu." (Anılardan Öyküler 2, 99/19-20)

$\checkmark$ "Babamdan çok korkardım. Çok döverdi beni." (Anılardan Öyküler 1, 49/12)

$\checkmark$ "Bir gün önce babamdan yediğim tokadı unutmuştum." (Anılardan Öyküler 1, 85/3)

$\checkmark$ "Bu yıl da sınıfta kalırsa babası artık okula göndermez." (Bir Küçük Osmancık Vardı, 89/15-16) 


\section{Diğer Sorumluluklar}

$\checkmark$ "Sonra Süzen kocasının paltosunu, şapkasını alırdı ve hemen mutfağa koşardı." (Gümüş Kanat, 20/25-27)

$\checkmark$ “Annem, çok geçmeden gülsuyu şişelerini getirerek Zeynep'e verdi; -Bunları içeri götürüver kızım." (Ötleğen Kuşu, 150/20-22)

$\checkmark$ "Sen karısı olup da kocana bakmadın, evin içinde en fazla harcanan o adam." (Kuklacı, 16/1-3)

$\checkmark$ "Baba, diyordu, kızın değil miyim, elbette sana hizmet edeceğim." (Kuklacı, 48/10-11)

$\checkmark$ "Para kazanırdı babam, getirir anneme verirdi. Annem de sandığında saklardı." (İnci'nin Maceraları, 39/10-12)

$\checkmark$ "Sen, ne kadar olsa kadınsın... Elin işe yaraşır... Şu kırık ibriği dikkatle sararsın..." (Tanrı Misafiri, 123/15-16)

$\checkmark \quad$ “...annem elinde yemek suyuna banılmış ekmeklerle avluya çıktı; -Gel pisi pisi pisi..." (Ötleğen Kuşu, 92/16-18)

$\checkmark$ "Mahalleye yeni taşındığımız için kadınlar 'safa geldiniz'e gelmişlerdi." (Falaka, 54/16-18)

$\checkmark$ "Bıçağı besmele ile çekip, deveciğin boynundaki tüyleri üfürerek iki yana açtı." (Yürekdede ile Padişah, 43/11-12)

$\checkmark$ "Babamın kerpiçten yaptığı, üç odalı bir evde otururuz." (Yankılı Kayalar, 7/22-23)

$\checkmark$ "Babası, önden atın başını çekiyordu... Annesi, Karadut, Kuzeyli, Bolugüzeli, Pembe, öbür buzağılar yürüyerek arabanın ardından geliyorlar; Sürmeli, dili dışarıda, ileri geri koşarak bu kısa göç yolculuğunun düzenini sağlıyordu." (Uç Minik Serçem, 122/9-13)

$\checkmark$ "Gündüz kime kızmışsa gece onun hıncını annemden çıkarır, benden çıkarır." (Tanrı Misafiri, 106/9-10)

$\checkmark$ "Babam dün kağnıyla, ilk çıkan buğdaylardan dört çuval getirmişti." (Ötleğen Kuşu, 145/9-10)

$\checkmark$ "Bugüne kadar beni anlamak hiçbirinizin aklına gelmedi. Beni sadece sizlere para yetiştirmekle görevli bir insan saydınız." (Kuklacı, 36/6-8)

$\checkmark$ "Amca onun babası çok fakir. İş bulursa çalışır. İş bulamazsa kahvede otururmuş." (Kuklacı, 64/5-6)

$\checkmark$ "Adam aç olduğundan, kadın ocağa yağ koymuş da, kümesten yumurta almaya gitmiş. Bu adam da yorgun olduğundan, yemek pişene kadar köşeye yaslanmış, uyuyuvermiş." (Keloğlan Masalları, 48/28-31)

$\checkmark$ "Günlerden bir gün kadının kocası, eşeğine iki tay, iki kile buğday yüklemiş, değirmene öğütmeye gitmiş." (Keloğlan Masalları, 48/23-25)

$\checkmark$ "Para kazanırdı babam, getirir anneme verirdi. Annem de sandığında saklardı." (İnci'nin Maceraları, 39/10-12)

$\checkmark \quad$ “...babamın, taliplerime red cevabını verdiği menhus güne kadar daima açık dururdu...” (Hep $\mathrm{O}$ Şarkı, 23/8-9)

$\checkmark$ "Sen bir padişahsın, kızını da şehzadelere vermelisin." (Havaya Uçan At, 6/19-20)

$\checkmark$ "Çoğu babalar baca tütünü; ana güder kuzuyu..." (Evvel Zaman Iç̧inde, 22/21)

$\checkmark$ "Beklemekten canı sıkılan erkekler, köşedeki kahvede çay, kahve içiyorlar." (Domaniç Dağlarının Yolcusu, 21/3-4)

$\checkmark$ "Caminin karşısındaki küçük kahvede oturan iri yarı, siyaha yakın esmer, sakallı yüzüyle, heybetli babasını, devamlı iş gören, yemek pişiren, çamaşır yıkayan anasını hatırladı." (Bir Küçük Osmancık Vardı, 55/22-25)

$\checkmark$ "Babam bıraksa geceleri de binecektim bisikletime." (Anılardan Öyküler 1, 99/15-16)

$\checkmark$ "Babam gelsin, kalaylatmaya götürsün." (Al'lı ile Fırfırı 2, 178/10-11)

$\checkmark$ "Bir kül bulutu odayı kapladı. Babası söylendi." (87 Oğuz, 32/12-13)

\section{Tartışma, Sonuç ve Öneriler}

Çalışmanın bulgularından hareketle elde edilen sonuçlar şunlardır:

1. Çalışmadan elde edilen bulgulara göre, taranan eserlerde 77 defa dişil cinsiyeti aşağılayıcı söyleme rastlanmıştır. Tablo 1 incelendiğinde dişil cinsiyetin en çok küfür ve argo ifadelere malzeme edildiği tespit edilmiştir. Eksik etek, kahpe, oynak, yolsuz, aşüfte gibi sözlük birimlerle dişil cinsiyete 
gönderim yapılmıştır. Bu ifadelerin eserlerin hiçbir yerinde eril cinsiyet için kullanılmadığı dikkati çekmiştir. Bu nedenle de bahsi geçen sözlük birimlerin, eserleri okuyan çocuklar tarafından çağrışımsal cinsiyeti dişil olan sözcükler olarak kodlanması beklenir.

2. Taranan eserler eril cinsiyeti yüceltici söylemler bağlamında incelenmiş ve 41 veriye ulaşılmıştır. Bu verilerin içinde; evin reisinin erkek olması, cesur bir kadını nitelemek istenildiğinde 'erkek' sıfatının kullanılması, erkeğin kadın üzerinde her türlü hakka sahip olması gibi farklı konularda erkeği yücelten ifadeler mevcuttur. Kılıç ve Eyüp (2011) Türkçe ders kitaplarındaki toplumsal cinsiyet rollerini inceledikleri çalışmalarında benzer sonuçlara ulaşmıştır. Erkeklerin bilgili, uygar, zeki, girişken; kadınların ise çaresiz, sulugöz, korkak gibi sıfatlarla nitelendirildiği sonucuna varmışlardır. Bu durum, söz konusu eserleri okuyan ortaokul çağı çocuklar üzerinde erkeğin daha değerli bir cins olduğu yanılgısına sebebiyet verecektir.

3. Çalışmada dişil ve eril cinsiyetin günlük yaşamdaki rollerine ait bulgular, evin her türlü işi ve çocuğun bakımıyla ilgili işlerde dişil cinsiyetin belirgin bir şekilde daha etkin olduğunu göstermiştir. Tablo 4'te günlük yaşamdaki rollerle ilgili toplam $286(\% 100)$ veriye ulaşıldığı ve bunların $218^{\prime}$ inin (\%76,22'sinin) dişil cinsiyete, 68'sinin (\%23,77'sinin) eril cinsiyete ait roller olduğu görülmüştür. Günlük yaşamdaki rollerle ilgili bulgulardan sadece çocuğun eğitimiyle ilgili olma başlığında eril cinsiyetin üstünlüğü tespit edilmiştir. Evin temizliği, ocak-soba yakımı, çocuğun bakımı gibi diğer tüm alt başıklarda eril cinsiyet geri planda kalmıştır. Özer, Karataş ve Ergun (2019) da çalışmalarında Illköğretim Türkçe ders kitaplarındaki toplumsal cinsiyet rollerini incelemiş ve ders kitaplarında kullanılan görsellerde kadınların evle ilgili daha çok resminin bulunduğu sonucuna ulaşmışır. Bu sonuçlar çocukların dişil cinsiyetin evle ilgili işlerde birinci rolü üstlenmesi gerektiği anlayışı oluşturmasına vesile olabilir.

4. Çalışmada ortaokul öğrencileri için önerilen 100 Temel Eser'in adalet temelli cinsiyet algısı oluşturmadığı sonucuna ulaşılmıştır. Bu nedenle MEB'in 100 Temel Eser uygulamasına son vermesine bu açıdan da bakıldığında yerinde bir karar olduğu görülmüştür.

$\mathrm{Bu}$ çalışmanın sonuçları doğrultusunda benzer araştırmalar yapacak bilim insanlarına ve halihazırda görev yapan Türkçe öğretmenlerine öneriler şunlardır:

1. Taranan eserlerden seçilen tanıklarda, ortaokul öğrencilerinin alıcı söz varlığına kazandırılması beklenen sözcükler ve sözcük öbeklerinin (özellikle argo ve küfürlü ifadelerin) bilişsel ve zihinsel gelişimlerine uygun olmadığı tespit edilmiştir. Bu nedenle MEB'in ve Türkçe öğretmenlerinin kitap listeleri belirlerken bunlara dikkat etmeleri gerekir.

2. Öğretmenler tarafından öğrenciler için oluşturulacak okuma listelerine seçilecek kitapların adalet temelli cinsiyet algısı oluşturmaya katkı sağlayan kitaplardan seçilmesi uygun olacaktır.

3. Edebî eserleri sadeleştirilme çalışmaları değer kaybına uğrama endişesi ile eleştirilir. Ancak klasik olarak nitelendirilen bazı eserlerin bilimsel yöntemlerle metin revizyonuna tabi tutulup ortaokul öğrencilerine önerilmesi uygundur. Bu çalışmaların daha sistemli ve yaygın biçimde yapılması çocukların klasik eserlerle karşılaşmalarını hızlandıracaktır.

4. Çocuk kitaplarının görsel metinlerinin de cinsiyet algısını nasıl yansıttığı farklı çalışmalarla incelenebilir. Yazılı metinlerin resmedildiği görsel metinlerin incelendiği bu çalışmalarda da benzer sonuçlar çıkması beklenir.

5. Yabancı yazarlı çocuk kitaplarının da ayrı bir çalışmayla cinsiyet algısı bağlamında incelenip bu çalışmanın bulgularıyla karşılaştırıması alana katkı sağlayacaktır.

\section{Yazarların Katkı Oranı}

Bu makaleye birinci yazarın $\% 60$, ikinci yazarın $\% 40$ oranında katkısı vardır.

\section{Çıkar Çatışması}

Çıkar çatışması teşkil edebilecek bir durum yoktur. 


\section{Destek ve Teşekkür}

Bu makale "100 Temel Eser'de Cinsiyet Rollerinin Dile Yansıması" isimli yüksek lisans tezinden üretilmiştir. Tez konusunu belirleme ve tezi yazma aşamasında büyük katkısı olan rahmetli hocamız Doç. Dr. İlknur Karagöz'e şükranlarımızı sunarız.

\section{Kaynaklar}

Adler, A. (1999). Cinsiyetler arasında işbirliği. İstanbul: Payel Yayıncılık.

Akbalık, E. (2014). Dede Korkut kitabında bir cinsiyet rejimi olarak "erkeklik". Türkbilig, 27, 105-119. Aktaş, Ş. (2009). Edebî metin ve özellikleri. A.Ü. Türkiyat Araştırmaları Ensitüsü Dergisi(39), 187-200.

Arı, G. ve Okur, A. (2019). Öğrencilerin ilköğretim 100 temel eseri okuma durumu. Türkiye Sosyal Araştırmalar Dergisi, 17(3), 307-329.

Çolak, G. (2019). Toplumdilbilimi toplumsal cinsiyet ve dil. İstanbul: Bilge Kültür Sanat Yayıncılık.

Çubukçu, H. ve Sivaslıgil, P. (2007). 7. sınıf İngilizce ders kitaplarında cinsiyet kavramı. Dil Dergisi, 137(7), 7-17.

Dökmen, Z. Y. (2017). Toplumsal cinsiyet sosyal psikolojik açıklamalar. İstanbul: Remzi Kitabevi.

Ecevit, Y. (2012). Aile, kadın ve devlet işlerinin değerlendirilmesinde klasik ve yeni yaklaşımlar. Kadın Araştırmaları Dergisi(1), 9-34.

Fine, C. (2017). Toplumsal cinsiyet yanılsaması. İstanbul: Sel Yayıncılık.

Giddens, A. (2012). Sosyoloji. İstanbul: Kırmızı Yayınları.

Göktaş, Ö. (2020). Çocuk oyuncaklarındaki toplumsal cinsiyet olgusu. Medya ve Kültürel Çalışmalar Dergisi, 2(1), 29-34.

Güder, S. Y., Ay, A., Saray, F., ve Kılıç, I. (2017). Okul öncesi dönem çocuklarının izledikleri kısa filmlerin toplumsal cinsiyet kalıp yargıları açısından incelenmesi: Niloya örneği. Eğitimde Nitel Araştırmalar Dergisi, 5(2), 95-110.

Gümüşoğlu, F. (2016). Ders Kitaplarında Toplumsal cinsiyet 1928'den günümüze. İstanbul: Tarihçi Kitabevi.

Gündüz, O. ve Şimşek, T. (2011). Anlama teknikleri 1 uygulamalı okuma eğitimi. Ankara: Grafiker Yayınları.

Karasar, N. (2011). Bilimsel araştırma yöntemi. Ankara: Nobel Akademik Yayıncılık.

Kılıç, L. K. ve Eyüp, B. (2011). Illköğretim Türkçe ders kitaplarında ortaya çıkan toplumsal cinsiyet rolleri üzerine bir inceleme. ODÜ Sosyal Bilimler Enstitüsü Sosyal Bilimler Araştırmaları Dergisi, 2(3), 129-148.

Millî Eğitim Bakanlığı (2005). İlköğretim için 100 temel eser genelgesi.

Millî Eğitim Bakanlığı (2018). 100 temel eser listesi genelgesi.

Millî Eğitim Bakanlığı (2019). Türkçe dersi öğretim programı.

Moir, A. ve Jessel, D. (2002). Beyin ve cinsiyet erkeksi kadınlar-kadınsı erkekler. İstanbul: Pencere Yayınları.

Özer, D. A., Karataş, Z., \& Ergun, Ö. (2019). Analysis of gender roles in primary school (1st to 4th Grade) Turkish textbooks. Eurasian Journal of Educational Research(79), 1-20.

Powell, G. N. ve Greenhaus, J. (2010). Sex, gender and decision at the family. Journal of Management, 36(4), 1011-1039.

Şirin, M. R. (2007). Çocuk edebiyatına eleştirel bir bakış"çocuk edebiyatı nedir ne değildir?". Ankara: Kök Yayıncilık.

Tavşancıl, E. ve Aslan, E. (2011). içerik analizi ve uygulama örnekleri. İstanbul: Epsilon Yayıncılık.

Uluocak, Ş. ve Aslan, C. (2011). Kadın bakış açısından toplumsal cinsiyet rolleri. Çanakkale: Çanakkale Kitaplığı Akademi.

Vatandaş, C. (2001). Toplumsal cinsiyet ve cinsiyet rollerinin algılanışı. İstanbul Journal of Sociological Studies, 35, 29-56.

Yeşil, F. (2014). Ortaokul Türkçe ders kitaplarında cinsiyet ifadeleri ve toplumsal cinsiyet rolleri [Yayımlanmamış Yüksek Lisans Tezi]. Marmara Üniversitesi Eğitim Bilimleri Enstitüsü. 


\section{Araştırmada İncelenen Eserler}

Abasıyanık, S. F. (2016). Seçme hikâyeler. Türkiye İş Bankası Kültür Yayınları.

Alangu, T. (2017). Keloğlan masalları. Yapı Kredi Yayınları.

Bilbaşar, K. (2011). Yonca kız. Can Sanat Yayınları.

Boyunağa, A. Y. (2017). Yankılı kayalar. Timaş Yayınları.

Burdurlu, i. Z. (2009). Anılardan öyküler 1. Tudem.

Burdurlu, i. Z. (2009). Anılardan öyküler 2. Tudem.

Burdurlu, i. Z. (2016). Ülkemin efsaneleri. Tudem.

Canat, H. N. (2016). Bir küçük Osmancık vardı. Genç Timaş Yayınları.

Cumalı, N. (2016). Uç minik serçem. Cumhuriyet Kitapları.

Çalapala, R. \& Çalapala, N. (2017). 87 Oğuz. Bilge Kültür Sanat.

Gültekin, R. N. (2016). Tanrı misafiri. İnkılâp Kitabevi.

Güney, E. C. (2016). Evvel zaman içinde. Nar Yayınları.

Hikmet, N. (2017). Sevdalı bulut. Yapı Kredi Yayınları.

Ilgaz, R. (2017). Halime kaptan. Çınar Yayınları.

Karagöz, H. (2016). Ötleğen kuşu. Boyut Yayıncılık.

Karaosmanoğlu, Y. K. (2014). Hep o şarkı. Iletişim Yayınları.

Kemal, O. (2016). Inci'nin maceraları. Everest Yayınları.

Nihal, Ş. (2013). Domaniç dağlarının yolcusu. Timaş Yayınları.

Örs, i. (2017). Göl çocukları. Nemesis Kitap.

Rasim, A. (2016). Falaka. Can Sanat Yayınları.

Safa, P. (2016). Havaya uçan at. Damla Yayınevi.

Seyda, M. (2017). Gururlu peri. Bilge Kültür Sanat.

Seyfettin, Ö. (2016). Yalnız efe. İnkılâp Kitabevi.

Tansel, O. (2009). Al'Iı ile firfırı masallar (Cilt 1). Elips Kitap.

Tansel, O. (2009). Al'Iı ile fırfırı masallar (Cilt 2). Elips Kitap.

Tuğcu, K. (2016). Yer altında bir şehir. Bilge Kültür Sanat.

Tuğcu, K. (t.y.). Kuklacı. Damla Yayınevi.

Uçuk, C. (2017). Gümüş kanat. Bilge Kültür Sanat.

Yesari, M. (2015). Bağrıyanık Ömer. Bige Kültür Sanat.

Yıldız, B. (2016). Arılar ordusu. Özyürek Yayınevi.

Zarifoğlu, C. (2016). Serçekuş. Beyan Yayınları.

Zarifoğlu, C. (2016). Yürekdede ile padişah. Beyan Yayınları.

Zorlutuna, H. N. (2015). Benim küçük dostlarım. Timaş Yayınları.

\section{Introduction}

\section{Extended Abstract}

Human beings are referred to as male and female in all cultures around the world depending on biological reasons. These two sexes differ from each other due to innate hormonal, physical and cognitive differences. Apart from this, the cultural understanding of the environment in which men and women live tries to attribute some concrete and non-objective characteristics to these two genders, and this situation is called as gender differences.

Gender stereotypes between the two sexes begin in childhood period. While the colours of clothes and goods chosen for boys and girls are determined according to gender, toys are produced in two separate categories as "for girls" and "for boys". When children reach school age, they start to be influenced by the social environment. In this age, children are not only affected by their friends and teachers. Children who learn to read begin to be affected by all kinds of written material, either positively or negatively. Children create a world view for themselves with the experience they have had and the books they have read. Before this view is shaped in a negative way, it is necessary to introduce the child with works that will create a justice-based gender perception. 
Breaking the perception which depends on injustice between men and women is only possible with education. The desired behavioural change can occur either by the child's internalization of what is happening around her/him through her own life, or by internalizing the reading books she/he chooses under the guidance of a good teacher. In this sense, Turkish lessons and teachers are important in terms of providing students with more works than other lessons.

It is aimed in this study to determine whether a justice-based gender perception is presented in children's books. In accordance with this purpose, the questions whose answers are sought in the research are as follows:

Has the perception of gender reflected in children's books?

What indicators meet gender perception in children's books?

Do children's books accurately reflect the justice-based gender perception?

Can the children's books included in the 100 Basic Works be confidently recommended to students within the scope of the Turkish course in order to create a justice-based gender perception?

\section{Method}

The research that has been done in line with this purpose has the characteristics of scanning model. Since the 100 Basic Works Implementation has been recently annulled, books that have been most read by the secondary grade students are assumed to be those in this list in the study. . Works that have been examined in the study were chosen among the 100 Basic Works list which was recommended to the secondary school students by the Ministry of Education in 2005.100 Basic Works consists of works from Turkish and World literature. 100 The works of foreign authors in 100 Basic works List were not included in the study due to the fact that they would not reflect the Turkish lifestyle and their gender perception. In this study the gender perception in 100 Basic Works, depending on the intra-textual context, has been examined at sentence level. Works in literary genres such as poetry, essay, proverb, idiom, quotations, rhyme, chansonette, lullaby were not included in the study because of their compilation nature and the absence of a narrative context. In this study which aims to describe the justice-based gender perception and its reflection on language, the data obtained from the specified categories in the context of feminine and masculine gender in the narratives of the 100 Basic Works, which was recommended by Ministry of Education in 2005, has been analysed by frequency analysis technique.

\section{Result and Discussion}

The results obtained from the findings of the research are as follows:

1. According to the findings obtained from the study, derogatory discourses about feminine gender have been encountered 77 times in the scanned works. Some dictionary units such as incomplete skirt, bitch, bed bunny, abusive, hussy are used to refer feminine gender. It has been noted that these dictionary units are not used for masculine gender anywhere in the works. For this reason, the dictionary units in question are expected to be coded by the children who read these works as words whose associative meanings are feminine gender

2. The scanned works have been examined in the context of expressions that dignify masculine gender and 41 data have been obtained. In this data; There are expressions that glorify men on different issues such as being the head of the house, using the adjective "man" when trying to describe a brave woman, and the man having all kinds of rights over women. This situation will cause the misconception that masculine is a more valuable gender among secondary school children who read the works in question.

3.Findings about the roles of the female and male sex in daily life have shown that the female gender is significantly more active in all kinds of household chores and childcare.

4.In the study, it has been concluded that the 100 Basic Works that were recommended for secondary school students do not create a justice-based gender perception. So, the decision of annulment of 100 Basic Works by Ministry of Education is seen as an appropriate one in this respect.

1.In line with the results of this research, suggestions for scientists who will conduct similar research and Turkish teachers who are currently working are as follows: 
2. In the witnesses selected from the scanned works, it has been determined that the words and word groups (especially slang and abusive expressions) that are expected to be introduced into the recipient vocabulary of secondary school students are not suitable for their cognitive and mental development. For this reason, Ministry of Education and even teachers of Turkish should pay attention to this issue in their book lists.

3. The books that will be selected to form a reading list for students by teachers should consist books which can contribute to create a justice-based gender perception

4. That recommending literary works to secondary school students directly so that they cannot lost their importance is not true. If these works are thought to be read by everyone, they can be transferred from secondary school to high school level.

5. How visual texts of children's books reflect the perception of gender can be examined with different studies. Almost the same results are expected to be obtained in a study in which written text are visualised and visual texts are examined.

6. Children books that are written by foreign authors can be studied in terms of justice-based gender perception in a different study and the differences between the findings of these studies can be evaluated. 